\title{
Clocks for all seasons: unwinding the roles and mechanisms of circadian and interval timers in the hypothalamus and pituitary
}

\author{
Shona Wood and Andrew Loudon \\ Faculty of Life Sciences, University of Manchester, Manchester M13 9PT, UK
}

Correspondence should be addressed

to A Loudon

Email

andrew.loudon@

manchester.ac.uk

\begin{abstract}
Adaptation to the environment is essential for survival, in all wild animal species seasonal variation in temperature and food availability needs to be anticipated. This has led to the evolution of deep-rooted physiological cycles, driven by internal clocks, which can track seasonal time with remarkable precision. Evidence has now accumulated that a seasonal change in thyroid hormone (TH) availability within the brain is a crucial element. This is mediated by local control of TH-metabolising enzymes within specialised ependymal cells lining the third ventricle of the hypothalamus. Within these cells, deiodinase type 2 enzyme is activated in response to summer day lengths, converting metabolically inactive thyroxine $\left(T_{4}\right)$ to tri-iodothyronine $\left(T_{3}\right)$. The availability of $T H$ in the hypothalamus appears to be an important factor in driving the physiological changes that occur with season. Remarkably, in both birds and mammals, the pars tuberalis (PT) of the pituitary gland plays an essential role. A specialised endocrine thyrotroph cell (TSH-expressing) is regulated by the changing day-length signal, leading to activation of TSH by long days. This acts on adjacent TSH-receptors expressed in the hypothalamic ependymal cells, causing local regulation of deiodinase enzymes and conversion of $\mathrm{TH}$ to the metabolically active $\mathrm{T}_{3}$. In mammals, the PT is regulated by the nocturnal melatonin signal. Summer-like melatonin signals activate a PT-expressed clock-regulated transcription regulator (EYA3), which in turn drives the expression of the TSH $\beta$ sub-unit, leading to a sustained increase in TSH expression. In this manner, a local pituitary timer, driven by melatonin, initiates a cascade of molecular events, led by $E Y A 3$, which translates to seasonal changes of neuroendocrine activity in the hypothalamus. There are remarkable parallels between this PT circuit and the photoperiodic timing system used in plants, and while plants use different molecular signals (constans vs EYA3) it appears that widely divergent organisms probably obey a common set of design principles.
\end{abstract}

Key Words

- pars tuberalis

- melatonin

- Eya3

- thyroid hormone

- thyrotrophin

- photoperiod

- circadian
Journal of Endocrinology (2014) 222, R39-R59 http://joe.endocrinology-journals.org DOI: 10.1530/JOE-14-0141 Printed in Great Britain

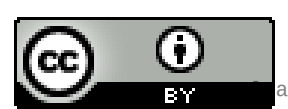

This work is licensed under a Creative Commons Attribution 3.0 Unported License. 


\section{Introduction}

In virtually all habitats, even the tropics, there are marked seasonal changes in temperature, precipitation and food availability. This provides a powerful selection pressure, which has led to the evolution of long-term timing mechanisms allowing organisms to predict key environmental changes. Mammals exhibit a remarkably wide spectrum of seasonal physiological adaptations, which includes annual cycles of growth, metabolism, thermogenesis, fattening and weight loss, hibernation, migration, moulting and pelage growth, and sexual behaviour, all of which are synchronised by internal timing mechanisms and provide an adaptive seasonal programme. This adaptive seasonal programme can be remarkably precise, for example, the median onset of birth dates for the arctic caribou varies by less than 4 days/annum (Post \& Forchhammer 2008). Many of our domesticated species retain their seasonal ancestry for many processes, including reproduction, growth and moult cycles, and this remains a dominant feature of most animal production systems around the world.

Seasonal changes in food availability and temperature might be predicted to serve as cues, timing activation of reproductive and other neuroendocrine circuits in birds and mammals. However, there is now overwhelming evidence that seasonal changes in day length (photoperiod) provide the primary environmental cue for a diverse range of organisms. In contrast to all other environmental cues, photoperiod offers a highly predictive signal that can be reliably used by both plants and animals to activate reproductive and growth processes at the most appropriate time of year. In small mammals with short gestation periods, breeding typically occurs in response to increasing day lengths in the springtime ('long-day (LD)' breeders). But with a progressive rise in body size, and longer gestation periods, larger mammals such as sheep and deer need to mate in the autumn ('short-day' breeders).

\section{The photoperiodic response}

The photoperiodic response of seasonal animals is known to involve a mechanism for registering changes in day length, and translating them into a neuroendocrine response. This 'photo-neuroendocrine system' was first defined as such by Berte and Ernst Scharrer in 1964 (Korf et al. 1998) and is a recognised universal feature of vertebrate and invertebrate responses to environmental change. The process of photoinduction is genetically programmed and driven by a conserved molecular mechanism in all tetrapods. A typical robust read-out of the seasonal response is seen in the expression of a seasonal pituitary prolactin rhythm, which is activated by long photoperiods, driving moult cycles in birds and mammals (Fig. 1). In small short-lived mammals such as Siberian hamsters, LD-activated prolactin secretion is suppressed by exposure to short days (SD), leading to marked changes in pelage and development of a white winter coat, but following prolonged exposure to SD, prolactin concentrations rise (i.e. the photo-neuroendocrine system becomes 'refractory') restoring the dark agouti summer coat in hamsters. Such responses are a universal feature of photoperiodic species, in which the initial response to photoperiod reverts over many weeks or months leading to a reversal of phenotype (Fig. 1). This refractory mechanism is common to virtually all seasonally breeding mammals that are sensitive to photoperiod change, including marsupial lineages (Brinklow \& Loudon 1993).
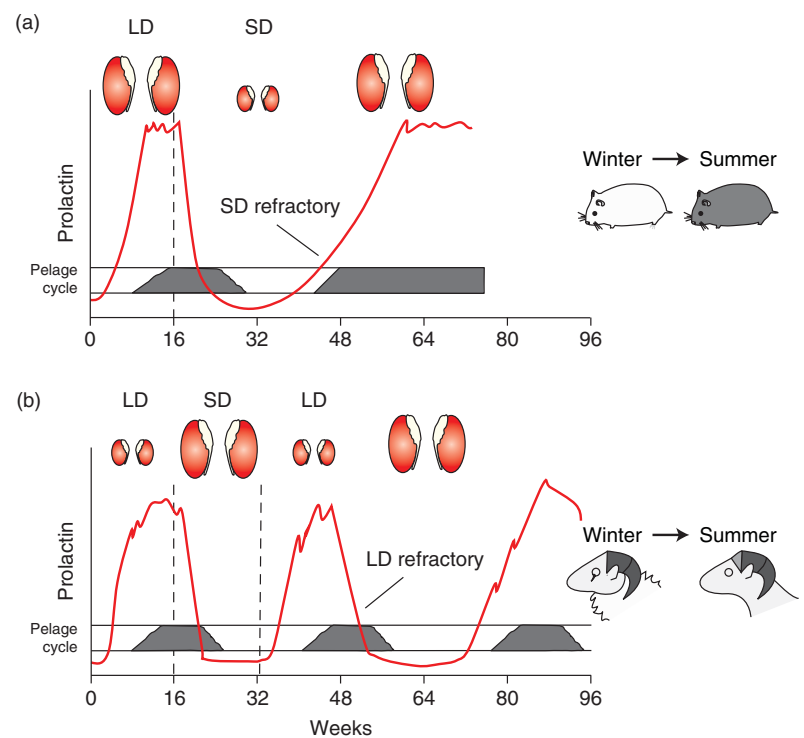

Figure 1

The seasonal prolactin rhythm and the associated pelage/moult and testis cycle in (a) male Siberian hamster and (b) male sheep exposed to long days (LD, $16 \mathrm{~h}$ light: $8 \mathrm{~h}$ darkness) and short days (SD, $8 \mathrm{~h}$ light: $16 \mathrm{~h}$ darkness). LD activates and SD inhibits prolactin release, driving pelage/moult responses. In the sheep, SD exposure activates the reproductive axis and LD leads to regression. Conversely in the hamster, LD activates the reproductive axis, and SD exposure leads to regression. Prolonged SD results in the development of photo-refractoriness with prolactin secretion resuming from 16 to 38 weeks (SD refractory state). This reversion to an LD-like state leads the coat to change from the white, winter pelage to the agouti, summer pelage and activation of the testis. In sheep, exposure to prolonged LD results in an initial refractory response from 12 to 36 weeks (LD refractory state). This merges into the expression of the circannual cycle; horn growth is suppressed during the winter leaving a permanent record of the cycles as rings in the horns. Adapted from Lincoln et al. (2003), first printed in Journal of Endocrinology.

Published by Bioscientifica Ltd 
In many small short-lived species (e.g. hamsters), refractoriness to SD signals is a widespread feature, but once established, animals remain 'locked' into a LD phenotype irrespective of how long they are exposed to SD signals. It is important to note that the reproductive rhythm is species-specific, and not phased to that of prolactin (i.e. in hamsters, reproductive activation and prolactin secretion are co-incident as both are springtime related). In long-lived species, long-term rhythms are established following prolonged exposure to fixed photoperiods, translating into cycles of neuroendocrine regulation of approximately 1 year in duration. These have been termed 'circannual' cycles and are a recognised feature of the biology of all long-lived vertebrate species which breed over several different seasons (Gwinner 1981, Woodfill et al. 1994). This is exemplified in the seasonally breeding sheep by the generation of long-term rhythms of prolactin, which drive the moult cycle (Fig. 1). In many seasonal species, including sheep and birds (Gwinner \& Dittami 1990), the generation of sustained long-term rhythms requires exposure to LD conditions, and generally circannual cycles do not emerge unless animals are housed in artificial summer day lengths. Thus, a photoperiodic read-out is clearly a requirement for generation of circannual rhythm in such animals (Lincoln et al. 2006, Dardente 2012). We return to this issue below when we consider some of the molecular mechanisms known to drive LD responses, and their regulation by the circadian clock. Circannual rhythms are also dominant characteristic of the reproductive biology of many tropical species. For instance, even when species such as the tropical axis deer are transferred to temperate environments, they retain persistent long-term rhythmicity in antler and testicular cycles, which are not synchronised with others in same population, or to external photoperiod (Loudon \& Curlewis 1988).

Seasonal variation in human hair growth and shedding (moulting) has been described; however these have not been related to seasonal variation in prolactin (Randall \& Ebling 1991). Seasonal variation in plasma testosterone in men has also been observed and suggested to be related to hair growth cycles (Randall \& Ebling 1991). Further evidence of seasonal cycles in humans has been noted in the seasonal variation in births; however, neuroendocrinologists do not agree that that reproduction is photo-responsive in humans (Bronson 1995).

The processes responsible for the generation of the circannual rhythm remains a subject of considerable interest to the biological timing field, but to date, rather little is yet known of the mechanisms involved, and the topic has recently been reviewed (Hazlerigg \& Lincoln 2011). Finally, in commonly used laboratory species such as mice, seasonal physiological responses are absent, and the reproductive system remains active irrespective of the photoperiod. But fascinatingly, aspects of the upstream signalling system driving seasonal neuroendocrine function remain intact, and this has been exploited in studies which have explored the genetic basis of seasonal timing.

\section{How circadian clocks might time seasonal reproduction: Bünning's hypothesis}

Photoperiodism implies that an organism must be able to discriminate either the length of light or nocturnal phase, or both. In 1936, Erwin Bünning, using both plant and insect models, developed the ground-breaking concept that photoperiodic species might use the endogenous timing system of the daily circadian clockwork. He proposed a lightrequiring phase (photophil) of approximately $12 \mathrm{~h}$, and a dark-requiring phase (scotophil) of approximately $12 \mathrm{~h}$, which both combine to a $24 \mathrm{~h}$ period (Bünning 1936). If light is only experienced in the photophil, then a SD response is triggered. A variant of this hypothesis was proposed by Colin Pittendrigh and colleagues (the internal co-incident timing model), in which light's only role is to entrain a multi-oscillator circadian system, with the phase of the dawn and dusk oscillators being set by the length of the photoperiod. Each of the oscillators will behave in a different manner, depending on the light-darkness cycle and assume different phase-relationships with the entraining cycle. Changes in the 'internal' co-incidence of these oscillators would then determine the photoperiodic response (Pittendrigh \& Minis 1964).

The Bünning's hypothesis and the later model of Pittendrigh are now widely accepted as the basis for photoperiodic time measurement in birds and mammals. The key experimental proof was provided by results from a series of studies reported by Nanda \& Hamner (1958) on the SD flowering response of soybean plants, in which $8 \mathrm{~h}$ light cycles were combined with nocturnal periods of 8-64 h. Only when the frequency of the light cycle fell within a fixed multiple of $24 \mathrm{~h}$ (i.e. 24,48 , and $72 \mathrm{~h}$ ) did plants exhibit an appropriate (SD) photoperiodic response. These 'resonance' protocols were later used in elegant studies of birds (whitecrowned sparrow, house finch and quail), in which a 6-h light period followed by dark periods comprising multiples of $24 \mathrm{~h}$ (i.e. $6 \mathrm{~h}$ light: $18 \mathrm{~h}$ darkness, $6 \mathrm{~h}$ light: $42 \mathrm{~h}$ darkness and $6 \mathrm{~h}$ light:66h darkness) resulted in a SD response (i.e. reproductive suppression). Cycles which were not delivered in multiples of $24 \mathrm{~h}$ (i.e. $6 \mathrm{~h}$ light: $30 \mathrm{~h}$ darkness and $6 \mathrm{~h}$ light:54 h darkness)-induced gonadal maturation

Published by Bioscientifica Ltd 
(LD response) (Hamner 1963, Follett \& Sharp 1969, Follett et al. 1974). In this study, light is posited to fall at a photosensitive phase on alternate days, triggering a ' $\mathrm{LD}^{\prime}$ response. Later studies on seasonal Syrian hamsters yielded similar results (Elliott et al. 1972). This now provides a framework for investigating the endocrine and molecular mechanisms underlying seasonal timing, and the challenge is to understand how changes in a circadian signalling system can be used to drive an annual cycle.

\section{Light input mechanisms and the rhythmic melatonin signal}

Mammals have diverged from birds and other vertebrates in the way they relay light-dark information and the hormonal signals involved. In mammals, the nocturnal production of the indoleamine hormone melatonin by the pineal gland provides a crucial step in the photoperiodic relay, and removal of the pineal prevents mammalian photoperiodic responsiveness (Hoffman \& Reiter 1965, Bittman et al. 1983, Carter \& Goldman 1983, Goldman 2001). In nonmammalian vertebrates, melatonin does not play a significant role in seasonal photoperiodic responses. The eye in mammals is the only photoreceptive organ and its removal also abolishes photoperiodic responses (Reiter 1980, Nelson \& Zucker 1981, Meijer et al. 1999). Birds and other nonmammalian vertebrates have extra-retinal and deep brain photoreceptors, therefore loss of the eyes has little effect on seasonal photoperiodic responses (Yoshimura 2013). Within the mammalian retina, rods and cones comprise the major image-forming photoreceptors, but in addition to this, there is a non-image-forming photoreceptor (melanopsin; OPN4), which is expressed in the ganglion cell layer. Photic inhibition of pineal melatonin persists in the absence of rods and cones (Lucas \& Foster 1999), indicating a role for the non-image-forming photoreceptor OPN4 in melatonin inhibition by light and circadian rhythms. The OPN4 photoreceptor is involved in both circadian re-setting mechanisms and pupillary light responses (Berson et al. 2002, Hattar et al. 2002, Lucas et al. 2003). Knockout of Opn4, in mice results in loss of light-dependent suppression of arylalkylamine $\mathrm{N}$-acetyltransferase mRNA (rate-limiting enzyme in melatonin synthesis) but only in mice that lack rod photoreceptors (Panda et al. 2003).

Changes in duration of the light-darkness cycle are decoded in mammals within the supra-chiasmatic nucleus $(\mathrm{SCN})$ of the hypothalamus. It has been proposed that altered phasing of clock genes, PER (PER1) and CRY, in the SCN leads to an encoding mechanism for tracking seasonal changes in photoperiod (Nuesslein-Hildesheim et al. 2000, Sumová et al. 2003, Hazlerigg et al. 2005, Inagaki et al. 2007, Naito et al. 2008). This SCN read-out of the photoperiod signal has all of the characteristics of an internal co-incidence timer, and is also reflected in changes in the patterns of SCN electrical activity (Brown \& Piggins 2009). The current dogma is that the mammalian pineal is controlled via a polysynaptic pathway from the SCN, relaying the light-entrained SCN rhythm into a rhythmic signal of circulating melatonin. This rhythm is characterised by a large nocturnal increase in circulating melatonin that closely reflects the duration of night period. This model is perhaps rodent-centric, as in other species there may be a role for direct photic regulation, independent of circadian input. For instance, in arctic reindeer, housed with artificial light cycles, there is an hourglass-like response to light-darkness cycles, with acute melatonin responses to dark exposure, and no evidence for an underlying circadian input (Stokkan et al. 2007, Lu et al. 2010). In such high-latitude species, the melatonin rhythm provides an accurate read-out of the prevailing photoperiod, but the endogenous melatonin cycle is only generated at times of year with a distinctive light-darkness cycle for a few months in the spring and autumn, and the rhythm dampens to extinction in the continuous darkness of the arctic winter (Stokkan \& Reiter 1994).

The primary mechanisms driving seasonal reproductive change resides in the neural control of the pattern of secretion of gonadotrophin-releasing hormone (GNRH) from the hypothalamus. Pulsatile release of GNRH drives luteinising hormone (LH) and follicle-stimulating hormone from the pituitary gland, which activates the gonads. Kisspeptin is a potent GNRH secretagogue, driving most aspects of reproduction in mammals (Oakley et al. 2009). RFRP3 (RFamide peptide) inhibits GNRH in the sheep and hamster; however, it can also activate GNRH in the hamster depending on photoperiod (Dardente et al. 2014). The GnIH gene in birds is equivalent to RFRP and is well characterised as having inhibitory effects on the gonadotrophic axis (Tsutsui et al. 2013). In sheep, the transition from the breeding to non-breeding season is associated with a dramatic reduction in the frequency of GNRH pulses, suppressing the gonadotrophin drive to the gonads, resulting in gonadal regression (Lincoln \& Short 1980, Goodman et al. 1982, Robinson et al. 1985, Barrell et al. 1992). The mass of the gonads, in mammals will change by approximately 10- to 15 -fold, while in birds this is over 100-fold, in response to season (Dawson et al. 2001). These seasonal changes in GNRH have long been recognised in mammals as being regulated by the melatonin signal. For instance, a series of studies

Published by Bioscientifica Ltd 
using pinealectomised and ovariectomised female sheep with constant-release oestradiol implants to mimic the mid-luteal phase of LH secretion reveal that artificial patterns of melatonin-mimicking summer or winter profiles were sufficient to drive the seasonal feedback effects of oestradiol on LH secretion (Goodman et al. 1981, 1982, Bittman et al. 1983, Robinson et al. 1985, Karsch \& Moenter 1990, Barrell et al. 1992). Infusion of longduration (winter-like) melatonin signals to pinealectomised Siberian hamster males blocks gonadal growth, and this effect is dependent on presentation of a regular repeated unbroken series of signals over many days (Carter \& Goldman 1983, Goldman et al. 1984). The expression of kisspeptin and RFRP is altered by photoperiod and melatonin in mammals (Simonneaux et al. 2012), linking them to seasonal reproductive changes.

The role of the SCN and the circadian clock in the interpretation of the melatonin signal is less clear. Early studies of Siberian hamsters revealed that SD-like effects of melatonin are blocked by SCN lesions (Bartness et al. 1991), but in Syrian hamsters gonadal responses to programmed infusions of melatonin are insensitive to the lesions of the SCN, or to the phase of the lightdarkness cycle at which the signal is presented (Maywood et al. 1990). The photoperiodic response to the melatonin signal, however, is sensitive to signal frequency, albeit in a range far greater than that which operates within the circadian system (Maywood et al. 1992, Grosse et al. 1993, Stirland et al. 1996).

The potential involvement of the circadian timing system has been explored further in studies of the Tau mutation in the Syrian hamster. Here, circadian activity cycles are accelerated from 24 to $20 \mathrm{~h}$, as a consequence of a gain-of-function mutation in a key kinase (casein-kinase $1 \varepsilon$ ) involved in the phosphorylation of PER proteins (Lowrey et al. 2000, Meng et al. 2008). As a result of this mutation, melatonin rhythms in Tau hamsters are also generated every $20 \mathrm{~h}$ (Lucas et al. 1999). Tau hamsters do remain photoperiodic, but require photoperiod cycles presented in $20 \mathrm{~h}$ patterns in order to mount appropriate neuroendocrine responses. Tau hamsters cannot entrain properly to $24 \mathrm{~h}$ cycles, nor can they respond to short photoperiods in a $24 \mathrm{~h}$ cycle; in these conditions, they remain reproductively active in a ' $\mathrm{LD}^{\prime}$ ' state. However, when maintained in continuous darkness, allowing the free-running melatonin rhythm to operate, Tau hamsters undergo testicular regression at a $20 \%$ more rapid rate than their WT counterparts under the same conditions (Loudon et al. 1998). Are such differences between Tau and WTs a consequence of an accelerated melatonin cycle, or has this circadian mutation also perturbed the response to the hormone? Pinealectomised Tau and WT hamsters were exposed to artificial infusions of long-duration (reproductive inhibitory) melatonin signals presented at a range of frequencies from 16 to $28 \mathrm{~h}$. Remarkably, Tau hamsters responded to signals every 16 or $20 \mathrm{~h}$, but were refractory to longer-frequency signals. The WT animals in contrast only responded to 24 or $28 \mathrm{~h}$ frequencies. This suggests that there is approximately a 4-h shift in the frequencyresponse function to melatonin signals, correlating with the altered circadian period. Thus, there may indeed be a genetic basis, involving the core circadian clockwork, in the interpretation of sequential melatonin signals at the target tissue (Stirland et al. 1996), which we consider below when we look at the circadian read-out mechanisms that operate in a melatonin-target tissue.

\section{Melatonin receptors: unexpected distribution and expression in the pituitary}

Two subtypes of high-affinity G-protein-coupled melatonin receptors have been identified, termed MT1 and MT2. MT1 is thought to be principally concerned with photoperiodic signal transduction (Reppert 1997). MT2 has a restricted expression, being largely absent in the hypothalamus or pituitary of adult mammals, while in photoperiodic Siberian hamsters MT2 appears to be a pseudogene (Weaver et al. 1996). A related receptor has been identified in mammals as an orphan G-proteincoupled receptor, Gpr50 melatonin-related receptor (Reppert et al. 1996, Weaver et al. 1996). GPR50 is now identified as the mammalian orthologue of the highaffinity avian MEL1C receptor, but has undergone rapid evolution in the mammalian lineage (Dufourny et al. 2008) and lost its capacity to bind to melatonin. In mammals, GPR50 expression in the brain is concentrated in circumventricular hypothalamic areas, adjacent to or overlapping with photoperiodic deiodinase enzyme regulation, and here, it is under strong photoperiodic regulation (Barrett et al. 2006). Knockout of this gene in mice leads to aberrant leptin responses and abnormal thermogenic responses to food restriction (Bechtold et al. 2012). The physiological function of GPR50 in seasonal mammals remains a fascinating avenue for further enquiry.

Given the importance of melatonin in the regulation of seasonal neuroendocrine function, one logical proposition for the site of action would be the hypothalamus. In pinealectomised Siberian hamsters, lesions of the melatonin-receptor expressing dorso-medial nucleus (DMN) block metabolic and reproductive responses to

Published by Bioscientifica Ltd 
long-duration melatonin infusions (Ebling \& Barrett 2008, Leitner \& Bartness 2011). However, comparative in vitro autoradiography using a radio-labelled analogue of melatonin, 2-iodo melatonin and in situ hybridisation studies for MT1 have mapped the sites of action of melatonin in the brain across a wide range of seasonal mammals, and remarkably have failed to localise a single common hypothalamic region (Morgan et al. 1994). Indeed, in some species such as ferrets and seasonal wallabies, melatonin receptors cannot be detected in the brain (Paterson et al. 1992, Weaver et al. 1996, Hinds \& Loudon 1997).

Unexpectedly, the pars tuberalis (PT) of the pituitary gland is a site in which melatonin binding is consistently observed in a wide range of seasonally breeding mammalian species (Morgan et al. 1994). The PT sits at the interface between the median eminence and the main pars distalis (PD) regions of the anterior pituitary (Fig. 2). Developmentally, it emerges from the rostral tip region of Rathke's pouch, and contains a mixture of endocrine cells and folliculo-stellate (FS) cells which share a number of immunological markers with brain glial cells, including GFAP and S100 protein (Hazlerigg et al. 2001). The PT has a distinct developmental origin from the rest of the pituitary gland, involving the bHLH transcription factor hairy enhancer of split (HES1) as a PT-specific differentiating factor (Akimoto et al. 2010). Anatomically, the long portal vessels linking the capillary bed of the median eminence to the PT run through the parenchyma of the PT. Tanycyte processes originate from the hypothalamus project to the PT (Rodríguez et al. 2005), while PT FS cells form cistern-like structures that make close contact with the PT-thyrotrophs, portal capillaries and tanycytes (Fig. 2) (Wittkowski et al. 1999). The primary endocrine cell type of the PT is thyrotrophic, expressing both the $\alpha$ and $\beta$ sub-units of thyroid-stimulating hormone (TSH). These cells lack receptors for the hypothalamic thyrotropin-releasing hormone (TRH) (Bockmann et al. 1997), and do not respond to conventional hypothalamic outputs. In mammals, the MT1 receptor co-localises to the PT thyrotroph (Klosen et al. 2002, Von Gall et al. 2002, Johnston et al. 2006).

\section{Melatonin and the control of adenyl cyclase activity in the PT}

The primary role of the melatonin signal is to convey information relating to the length of the day. The discovery of melatonin receptors in the PT offers a useful target tissue for further studies. Melatonin receptors are predominantly coupled to the inhibitory $\mathrm{G}_{\mathrm{i}}$-protein linked with inhibition of cAMP synthesis and involved in inhibition of the classical transduction cascades induced by cAMP (PKA, CREB phosphorylation and MAPK activity; Morgan et al. 1989, Hazlerigg et al. 1991). Therefore, a model could be that nocturnal suppression of cAMP would lead to a time-release mechanism, conveying photoperiodic time. Prolonged exposure of PT cells to melatonin, however, causes sensitisation of adenylate cyclase to stimulation when melatonin is withdrawn (Hazlerigg et al. 1993), leading to a rise in cAMP levels at dawn (Hazlerigg et al. 1993, Barrett et al. 2003a,b). It is this dual repressive/ sensitisation mode of action of melatonin that accounts for the dawn activation of some PT-expressed genes. Melatonin does not just act as a repressor, as many PT genes are acutely activated by melatonin, as discussed below (Dupré et al. 2008, Fustin et al. 2009, West et al. 2013).

The Per1 transcript is expressed in the melatoninproficient mouse strain $\mathrm{C} 3 \mathrm{H} / \mathrm{HeN}$, in both the $\mathrm{SCN}$ and the PT of mice, and in the latter case is activated at dawn, coincident with the decline in melatonin secretion (Sun et al. 1997). Analysis of Per 1 gene expression in the PT of the melatonin-deficient mouse strain C57BL/6 reveals that expression is absent, in contrast to the situation in the SCN (Sun et al. 1997), furthermore, pinealectomy of Syrian hamsters and $\mathrm{C} 3 \mathrm{H} / \mathrm{HeN}$ mice abolishes PT Per expression, as does deletion of the MT1 receptor in the mice (Messager et al. 2001, Von Gall et al. 2002). This indicates a dependency on melatonin for the active regulation of Per1. However, PT cells exposed to melatonin for 8 or $16 \mathrm{~h}$ show similar cAMP levels, despite having markedly different photoperiodic responses, indicating that the adenylate-cyclase-sensitising effects of melatonin are not a sufficient mechanism to explain differential responses to melatonin-signal duration (Hazlerigg et al. 1993, Deneubourg et al. 2013). Furthermore, many of the oscillating genes within the PT lack cAMP-response elements (CRE) and have no link to cAMP.

The discovery of the PT as a major site of melatonin action now presents a paradox. How might a pituitary target site be involved in remodelling of hypothalamic neuroendocrine circuits - the hallmark of the seasonal response? The answer to this lies in the remarkable discovery of thyroid hormones (THs) as key seasonal switches and their control via a novel PT pathway.

\section{Role for THs in seasonal timing}

$\mathrm{TH}$ is crucially required for the expression of seasonal rhythms in multiple vertebrate species

Published by Bioscientifica Ltd 


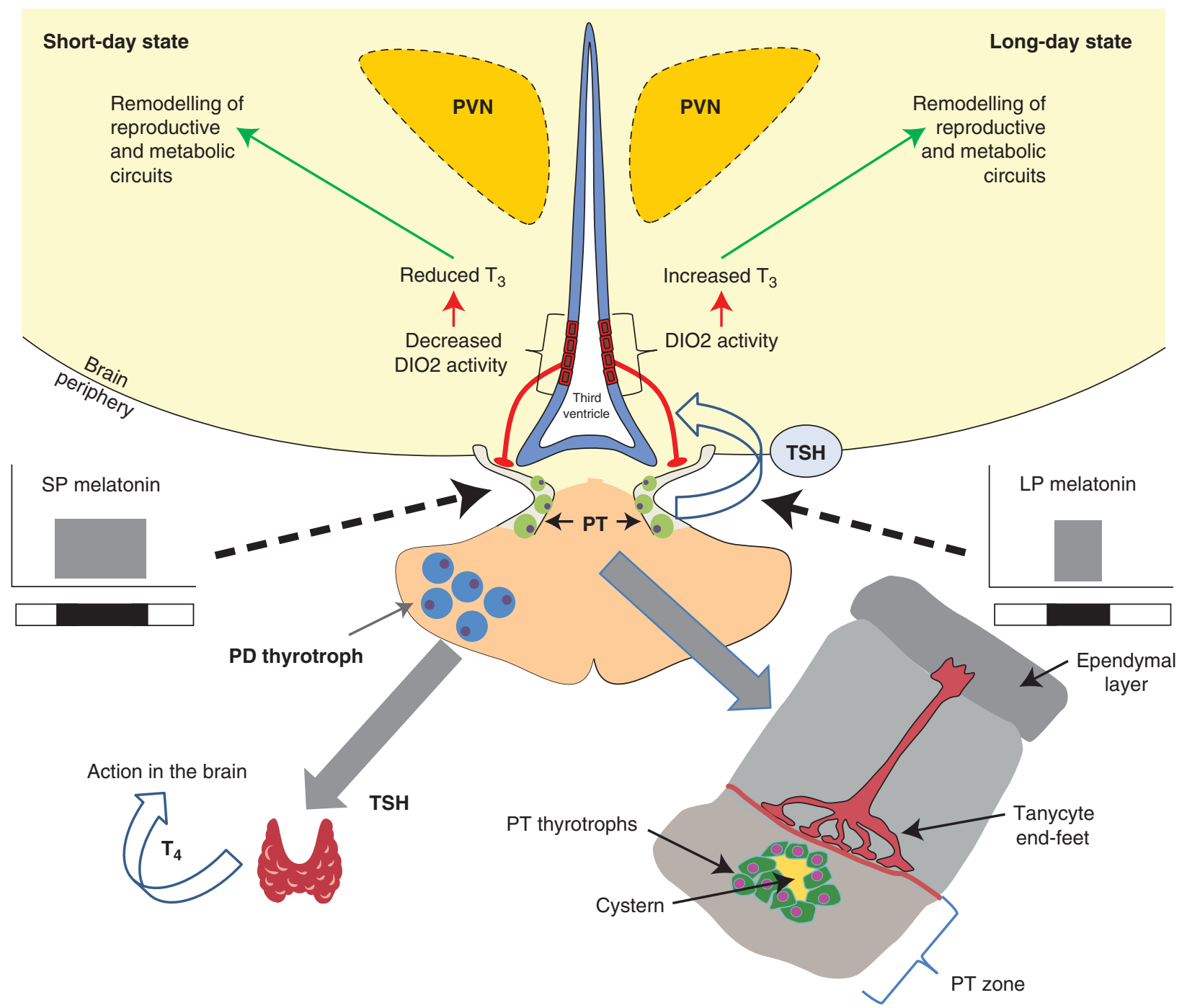

Figure 2

Retrograde action of TSH on ependymal cells in the hypothalamus. Photoperiod is encoded by the nocturnal melatonin signal that is sculpted by day length, generating short-duration signals in response to (long) summer day lengths. The prime site of action is the pituitary pars tuberalis. LD activation of TSH $\beta$ leads to an increase in deiodinase 2 activity in adjacent ependymal cells (tanycytes), which express the TSH receptor. This in turn leads to $L D$ augmentation of $T_{3}$, via conversion from $T_{4}$. The $T_{3}$ switch now

(Hazlerigg \& Loudon 2008, Yoshimura 2013). This ancient signalling molecule originated well before the divergence between the vertebrate and other deuterostome lineages. TH has even been linked to the control of breeding activity in Echinoderms and the primitive chordate Amphioxus (Lancelet) (Heyland et al. 2005). Early studies of birds (ducks, Benoit (1936) and starlings, Woitkewitsch (1940)) demonstrate that removal of the thyroid gland dramatically altered the seasonal response of gonads. Thyroidectomy (TX) blocks many of the seasonal responses to acts on other hypothalamic circuits, leading to remodelling of reproductive and metabolic processes. Importantly, the TSH-expressing cells of the PT lack the TRH receptor, therefore cannot be regulated by a conventional hypothalamus peptide (TRH). The PT thyrotrophs are organised with an internal cistern-like structure, perhaps allowing the action of TSH on hypothalamic cells.

photoperiod in the Japanese quail, and a single injection of thyroxine $\left(\mathrm{T}_{4}\right)$ can restore the seasonal response (Follett $\&$ Nicholls 1985). Subsequent TX studies in sheep revealed that the normal transition to anoestrous at the end of the winter is blocked and can be restored by administration of $\mathrm{T}_{4}$ (Nicholls et al. 1988, Webster et al. 1991a). In TX female sheep, the mechanisms involved in oestrogen and progesterone feedback appear normal, as does the frequency and amplitude of the GNRH and LH pulses (Webster et al. 1991a,b).

Published by Bioscientifica Ltd 
Studies of thyroid function have been extended to other seasonal ruminants (red deer) (Anderson \& Barrell 1998) exhibiting similar blockade of transition to anoestrus following TX. Sheep and deer are autumn-breeding species, with increasing day lengths in the spring terminating breeding activity. Remarkably, the effects of systemic treatment with $\mathrm{T}_{4}$ are only effective in terminating the breeding season in TX sheep when administered in the spring, while late summer or autumnal treatments have little effect on the onset of breeding (Billings et al. 2002). Further investigations of TX ewes using local constant-release micro-implants of $\mathrm{T}_{4}$ administered to the brain revealed that the springtime requirement for $\mathrm{TH}$ is localised to sites within the basal hypothalamic region (Anderson et al. 2003).

There may also be a role for TH transporters; MCT8 is a specific TH transporter that is regulated by photoperiod in Siberian hamsters and tanycytes in F344 rats. However, counter-intuitively MCT8 expression is increased with short photoperiods when hypothalamic tri-iodothyronine $\left(\mathrm{T}_{3}\right)$ levels are reduced (Hanon et al. 2010, Ross et al. 2011). In F344 rats, there is an upregulation of the thyroid transporter OATP1C1 (SLCO1C1) with long photoperiods, which is consistent with increased TH with long photoperiods. Therefore, the availability of TH to the hypothalamus seems to be an important factor in driving seasonal physiology, although it is currently unclear in which direction TH transporters, such as MCT8, transport $\mathrm{TH}$ (i.e. into or out of the cell).

\section{Regulation of TH by deiodinase enzymes}

A key discovery by Yoshimura et al. (2003), working on the Japanese Quail (Coturnix japonica), revealed a potential mechanism to account for the seasonally dependent action of $\mathrm{TH}$ in the hypothalamus. Intra-hypothalamic bioavailability of $\mathrm{T}_{3}$, the biologically active form of $\mathrm{TH}$, is governed through photoperiod-dependent changes in deiodinase gene expression (Yoshimura et al. 2003, Yasuo et al. 2005). Critically, these studies revealed that exposure to long photoperiods, which activates reproduction in quail, resulted in significant upregulation of the gene encoding the seleno-enzyme type 2 deiodinase (Dio2) within the ventral hypothalamic ependymal cell layer (tanycytes). These non-ciliated cells line the ventral wall of the third ventricle within the medial basal hypothalamus and have long basal processes, which terminate as end-feet in contact with the portal plexus of the median eminence (Akmayev \& Fidelina 1974, Yoshimura et al. 2003, Rodríguez et al. 2005). Dio2 removes iodine from the outer ring of $\mathrm{T}_{4}$, thus locally converting $\mathrm{T}_{4}$ to the metabolically active $T_{3}$. In turn, exposure to short photoperiods causes suppression of Dio2, but upregulation of Dio3 within these cells, which removes iodine from an inner ring of $\mathrm{T}_{4}$, leading to conversion to the inactive reverse $\mathrm{T}_{3}$ (Fig. 3 ). The net result is that significant local changes in concentrations of bioactive $\mathrm{TH}$ occur within the hypothalamus in a photoperiod-dependent manner, with elevated levels of $\mathrm{T}_{3}$ during long photoperiods (Fig. 3). This new model also offers insights into why responses of thyroidectomised animals to $\mathrm{T}_{4}$ are only effective when presented during long photoperiods, as its conversion requires LD-activated Dio2. $\mathrm{T}_{3}$ implants, in contrast, are an effective LD signal during short photoperiods (Barrett et al. 2007, Murphy et al. 2012).

The regulation of TH by photoperiod in the hypothalamus appears to be a conserved feature in several other vertebrate groups, including mammals and fishes (Hazlerigg \& Loudon 2008, Nakane et al. 2013). There is, however, a marked species variation in the extent of LD-induced Dio2 and SD-induced Dio3 within the hypothalamus. In Syrian hamsters, transfer from SD to LD induces Dio2, with no apparent effect on Dio3 (Revel et al. 2006, Barrett et al. 2007), while in Siberian hamsters, both enzymes are regulated, but the predominant change is SD-induction of Dio3 (Barrett et al. 2007, Herwig et al. 2012, Prendergast et al. 2013). In contrast, in European hamsters and the photoperiodic rat (F344 strain), the switch from SD to LD causes increased Dio2 expression and decreased Dio3 (Hanon et al. 2010, Ross et al. 2011). There are also marked differences in the extent of expression of these enzymes. In short-lived rodents Dio2 expression is limited mainly to the ependymal region (Barrett \& Bolborea 2012), whereas in sheep LD-induced DIO2 is expressed within the ependymal layer, the median eminence and tuberoinfundibular sulcus (Sáenz de Miera et al. 2013). Importantly, these $\mathrm{TH}$ changes occur in the same direction in all species so far studied, irrespective of whether they are autumn-breeding (sheep and deer) or spring-breeding (seasonal rodents, quail), presenting a paradox as to how the sign of the LDactivated TH signal is reversed in species with breeding patterns timed at other times of year. Therefore, regulation of local TH bioavailability within the hypothalamus is the dominant signal-driving LD reproductive responses.

How changes in tanycyte function and altered hypothalamic $T_{3}$ metabolism may impinge on neural pathways controlling seasonal breeding or other circuits regulating seasonal metabolic changes is less well understood, and has recently been reviewed (Bolborea \& Dale 2013).

Published by Bioscientifica Ltd 


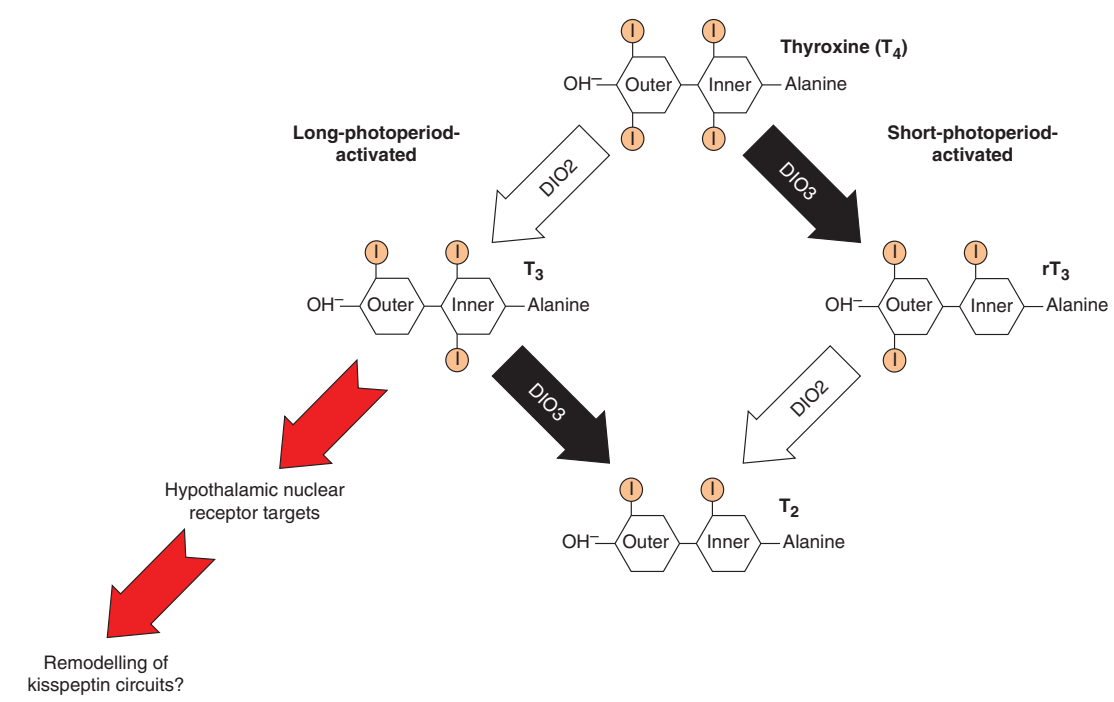

\section{Figure 3}

Seasonally dependent action of thyroid hormone (TH) through photoperiod-dependent changes in deiodinase enzyme expression. Thyroxine $\left(T_{4}\right)$ is the major circulating form of TH. The biological activity of $T_{4}$ is relatively low. Upon conversion to triiodothyronine $\left(T_{3}\right)$ through outer ring deiodination, biological activity is markedly increased. This conversion to the active form is mediated by type 2 deiodinase (DIO2) in the brain. $\mathrm{T}_{4}$ can be converted to an inactive form, reverse $\mathrm{T}_{3}\left(\mathrm{rT}_{3}\right)$ by inner ring deiodination mediated by DIO3. Both $\mathrm{T}_{3}$ and $\mathrm{rT}_{3}$ can be further metabolised by $\mathrm{DIO} 3$ or

As discussed earlier, there is a potential role for kisspeptin and RFRP3 in the regulation of seasonal reproduction (Simonneaux et al. 2013). A recent study has demonstrated that delivery of TSH in Siberian and Syrian hamsters induces DIO2 and restores Kisspeptin and RFRP expression to long photoperiod levels and reactivates the gonadal axis (Klosen et al. 2013). $\mathrm{T}_{3}$ injections administered to SD Siberian hamsters reactivated the gonadotrophic axis and led to LD levels of RF-amide peptides (Henson et al. 2013). This indicates that the action of TH on RF-amide neurons and subsequent seasonal control of GNRH secretion may be linked to the photoperiodic production of TSH within the PT.

\section{Role of the PT and TSH}

Two studies in Japanese quail and Soay sheep now lend support to the concept that TSH-expressing PT cells are key regulators of hypothalamic function. In this model, PTderived TSH acts as a local signal within the medial basal hypothalamus to regulate tanycyte Dio2 gene expression (Hanon et al. 2008, Nakao et al. 2008). In the seasonal quail model, reproductive responses to long photoperiods are very rapid, with a rise in LH in response after exposure to a single LD. Using this protocol, Yoshimura and colleagues
DIO2, respectively, leading to diiodothyronine $\left(T_{2}\right)$ formation. In short photoperiod, DIO3 is upregulated leading to reduced activity of TH. In long photoperiod, DIO2 expression is increased leading to the conversion of $\mathrm{T}_{4}$ to $T_{3}$, elevating bioactive $\mathrm{TH}$ in the hypothalamus. It is thought that altered hypothalamic $T_{3}$ metabolism may alter kisspeptin and RFRP3 levels leading to the regulation of seasonal reproduction, although there is currently no direct evidence for this link (Simonneaux et al. 2013).

screened for a time course of photoperiod-activated genes following photo-stimulation, and identified TSH $\beta$ as one of two early-response genes, expressed at $14 \mathrm{~h}$ during the first LD exclusively within the PT. This was followed by activation of Dio2 in the adjacent ependymal layer $4 \mathrm{~h}$ later (Nakao et al. 2008). Using i.c.v. administration of TSH, these authors demonstrated that TSH activates Dio2, in a cAMP-dependent manner, and initiates reproductive activation in short-photoperiod-suppressed birds. In sheep, a similar pathway operates, with LD activation of TSH and induction of DIO2 enzyme in the ependymal tanycytes of the ventral hypothalamus (Hanon et al. 2008; Figs 3 and 4). In both birds and mammals, the common $\alpha$ sub-unit is not regulated by photoperiod and remains constitutively expressed throughout the annual cycle in the PT. TSH acts on the G-protein-coupled TSH-receptor, and receptor fields for these are localised in the ependymal cell layer and also in the PT itself (Figs 3 and 4; Hanon et al. 2008). This also offers a new concept, whereby cAMP signalling in the PT is elevated in response to long photoperiods by a short-loop feedback of TSH on local receptors. There are striking differences in the speed of response of the TSH $\beta$ system in birds (quail) and mammals (sheep). In the former, TSH $\beta$ is activated within $14 \mathrm{~h}$ of the initial photo-stimulation (Nakao et al. 2008); this is in

Published by Bioscientifica Ltd 


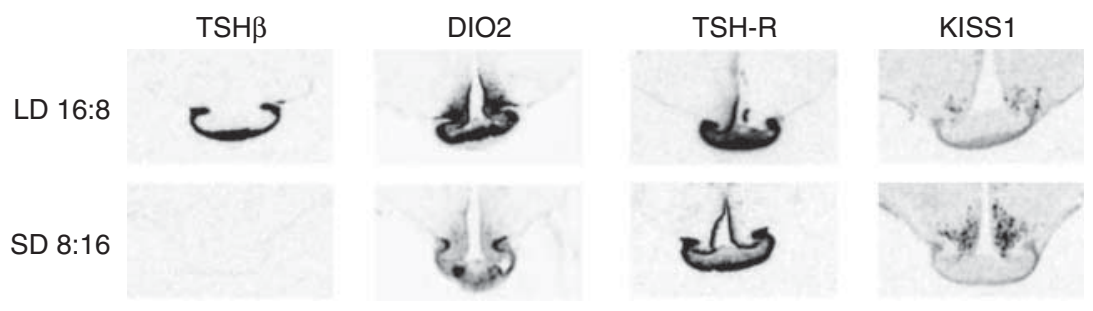

\section{Figure 4}

Photoperiod-controlled gene expression in the PT and hypothalamus. Autoradiographic images of radioactive in situ hybridisations carried out on tissue from Soay sheep with antisense probes to the $\beta$ sub-unit of thyroid-stimulating hormone $(T S H \beta)$, TSH receptor $(T S H-R)$, type 2 deiodinase (DIO2) and kisspeptin (KISS1). Sheep were acclimated under long days ( $16 \mathrm{~h}$ light: $8 \mathrm{~h}$ darkness) and short days ( $8 \mathrm{~h}$ light: $16 \mathrm{~h}$ darkness) for 6 weeks before sampling. There is a strong photoperiodic effect on pars tuberalis (PT) expression of TSH $\beta$. DIO2 and TSH-R expression in the median eminence (ME) and third ventricle of the hypothalamus are under photoperiodic control as is KISS1 expression in the adjacent arcuate nucleus (ARC). Adapted from Hazlerigg \& Loudon (2008), first published in Current Biology where images were kindly provided by $\mathrm{E} A \mathrm{H}$ Hanon and $\mathrm{G} C \mathrm{C}$ Wagner. contrast with sheep, in which there is a sustained rise in response over 15 days (Dardente et al. 2010; Fig. 5). Collectively, these studies now provide a model for the seasonal regulation of deiodinase enzyme expression, involving a 'retrograde' action of TSH from the PT on receptor fields in the ependymal tanycytes, driving local $\mathrm{TH}$ metabolism in the hypothalamus.

\section{Role of an ancient retinal-determining gene, EYA3, as a LD switch}

The photoperiodic induction of TSH $\beta$ as described earlier operates as an essential molecular switch, governing the changes in seasonal reproductive biology. But what regulates TSH $\beta$ ? In quail, an early-response gene in PT, activated by LDs is the induction of eyes absent 3 (Eya3; Nakao et al. 2008). Eya3 rises $14 \mathrm{~h}$ after the first exposure to a LD signal. In these studies, quails were exposed to an extreme photoperiod shift of from $6 \mathrm{~h}$ to $20 \mathrm{~h}$ of light, and Eya3 expression was shown to be matched closely to that of $T S H \beta$. The time course of activation of Eya3 in birds beyond the first LD has not been defined. Other studies and our own in mammals reveal a potentially longer and dynamic time course for Eya3 activation (Dardente et al. 2010, Dupré et al. 2010, Masumoto et al. 2010). In sheep, using RNA-seq, we have detected significant elevation of EYA3 on the first full LD cycle, co-incident with the early photophase (Loudon A, Burt DW, Yu L and Wood S, unpublished observations). Similar data have been obtained in mice, with weak induction on day 1 , and with a clear second peak at zeitgeber time (ZT) 20 from the first day of long photoperiod. By day 3 of LD in sheep, EYA3 is clearly induced, as is TSH $\beta$, and expression levels continue to rise over the following 2 weeks, but by day 15 there is a small evening peak at ZT16 (Fig. 5; Dardente et al. 2010). By day 28, this second peak at the end of the photophase is of similar amplitude to the early lightphase levels (Dupré et al. 2010). In sheep it is apparent that EYA3 exhibits a process of continuous dynamic activation over a period of at least 1 month following exposure to LDs, but critically, expression is confined to the photophase throughout (Fig. 5).

The eyes absent (EYA) proteins are highly conserved, from humans to insects, and were first described in relation to eye development in Drosophila. They are now known to be involved in the development of multiple organs (including the endocrine glands and parathyroid), innate immunity, DNA damage repair, angiogenesis, cancer metastasis and photoperiodism (reviewed in Tadjuidje \& Hegde (2013)). Not only are the EYA proteins conserved but so are the regulatory networks of PAX, SIX and DACH proteins with which they interact. EYA proteins exhibit a dual role, and can act both as phosphatase enzymes and also as transcriptional coactivators (Jemc \& Rebay 2007). The role of EYA3 in $\mathrm{TSH} \beta$ regulation has been investigated using the mouse and ovine promoter sequences in NIH3T3 and COS7 cell lines respectively (Dardente et al. 2010, Masumoto et al. 2010). This revealed that synergistic activation of TSH $\beta$ is by EYA3-SIX1-TEF (Fig. 5). EYA3 lacks a DNA-binding domain and therefore acts as a transcriptional co-activator with SIX1 binding to the DNA (Xu et al. 1997), a mechanism of action which is not dependent on the phosphatase action of the protein (Dardente et al. 2010). Activation of the TSH $\beta$ promoter is, however, dependent on a D-box element with in the promoter (Dardente et al. 2010). Using the mouse promoter constructs, a six binding site (So1 site) has also been identified as having an essential role in EYA3 and SIX1 activation of TSH $\beta$. The conclusion from this study is that TEF (HLF and DBP) binds to the D-element, and

Published by Bioscientifica Ltd 
Long days

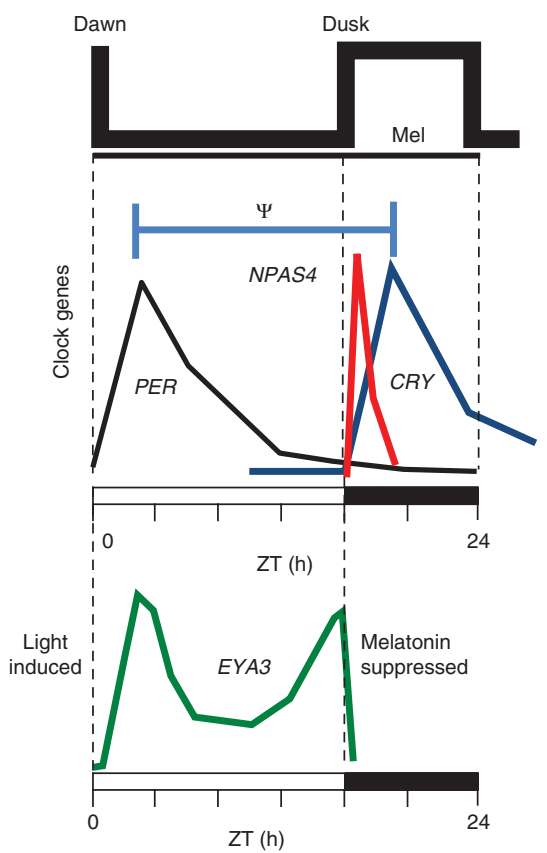

Short days

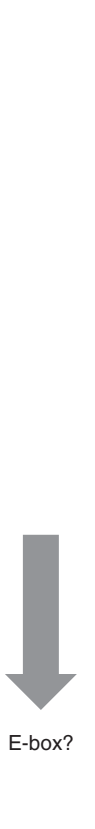

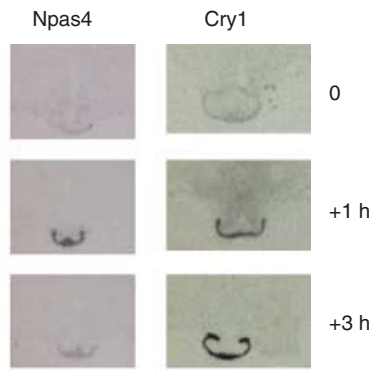
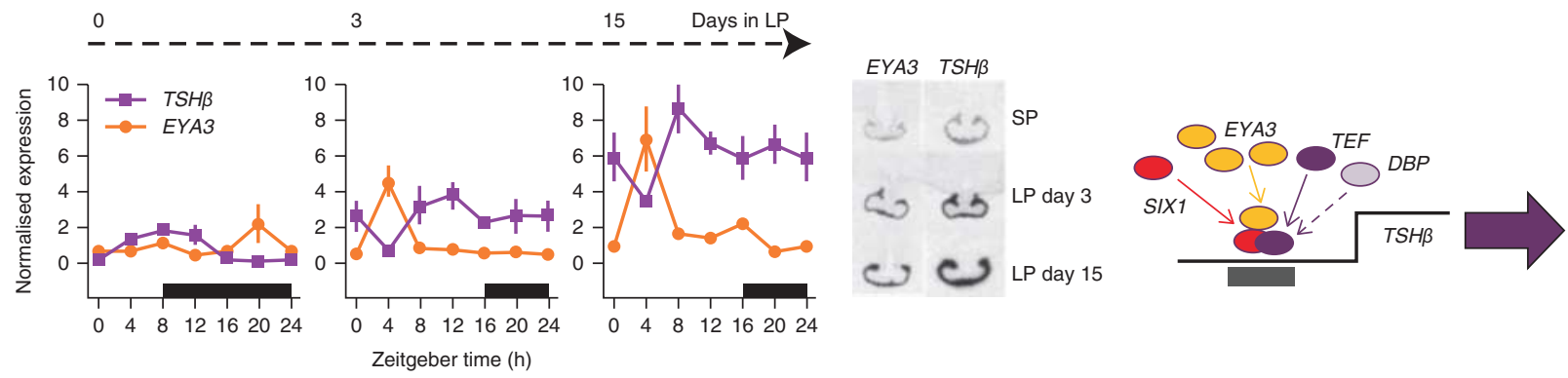

\section{Figure 5}

Decoding of the melatonin signal to produce a seasonal response. Decoding the melatonin signal involves changes in the temporal expression of circadian clock genes ( $P E R$ and $C R Y$ ). In the internal coincidence model, changes in the phase of $P E R$ and $C R Y$ gene expression are driven by the shifts in the offset and onset of melatonin secretion, such that the PER/CRY interval $(\psi)$ varies with photoperiod. $C R Y$ is the probable major regulator of the PT clock, driven by rising melatonin at dusk. NPAS4 operates as the key upstream switch, and is acutely activated by melatonin, driving the expression of CRY. EYA3 has multiple E-box binding sites for clock genes, and the phase of EYA3 expression is set by the PT clock, leading to a rise $12 \mathrm{~h}$ after melatonin. With short day (SD) lengths, CAMP repression by melatonin inhibits the full activation of EYA3. The system is de-inhibited in response to long days (LD), when EYA3 expression is coincident with light.

EYA3-SIX1 binds to the So1 site, activating TSH $\beta$. Intriguingly, SIX proteins can be repressors in the absence of EYAs (Tadjuidje \& Hegde 2013). In conclusion, it now appears that SIX1 is an essential co-factor for EYA3induced expression of the TSH $\beta$ promoter (Dardente et al. 2010, Masumoto et al. 2010), directly linking EYA3 and SIX1 to seasonally regulated reproductive cycles. In this
Thus, a clock gene rhythm and CAMP control regulate expression. EYA3 is a strong coactivator of TSH $\beta$ expression in the pars tuberalis in synergy with $T E F, S I X 1$ and $D B P$. The lower panel illustrates the induction of EYA3 and $T S H \beta$ on transfer to LD. Sheep were acclimated to $8 \mathrm{~h}$ light/day and transferred to $16 \mathrm{~h}$ light/day (LP) by acutely delaying lights off. Tissue was collected at $4 \mathrm{~h}$ intervals throughout $24 \mathrm{~h}$ on SD and the 3rd and 15th day following LD. The black horizontal bar in each graph indicates when lights were off during each sampling period. Data are mean \pm s.E.M. of $n=3$ animals per sampling point, with representative images from autoradiographic images of radioactive in situ hybridisations showing peak expression levels of $E Y A 3$ and $T S H \beta$ in each of the sampling periods. The lower panel is adapted from (Dardente et al. 2010), first published in Current Biology. Data on Npas4 and Cry1 adapted from West et al. (2013).

model, EYA3 is the dynamic element, with little evidence that other elements are under photoperiodic control.

A fascinating feature of this control system is that the photoperiodic induction mechanism appears to be conserved right down to the regulation of $\mathrm{T}_{3}$ production in laboratory mice. Detailed analysis of the D-box element reveals that the murine form is even more

Published by Bioscientifica Ltd 
efficient in terms of driving TEF-dependent expression of TSH $\beta$ than the ovine D-box. Thus, it appears while mice may retain a residual photoperiodic mechanism, it fails to couple to reproductive and metabolic circuits in the brain and may perhaps be over-ridden by other (stronger) inputs such as olfactory and nutritional cues. This uncoupling, however, is likely to occur downstream of $\mathrm{DIO} 2$ and $\mathrm{TH}$ availability, as there is Dio2 regulation in a melatonin-proficient strain of mice (Ono et al. 2008).

\section{Clock genes, the melatonin signal and the PT}

The mechanisms regulating EYA3 remain of considerable interest. Expression is tightly sculpted to the photophase on LDs, activated at dawn following the decline in melatonin signal and is acutely suppressed by melatonin at the onset of the dark phase (Dardente et al. 2010; Fig. 5). In the PT, the control of EYA3 is akin to the Bünning's external co-incidence timing mechanism, which sets a 'photosensitive phase' and in which the circadian clock times EYA3 expression to approximately $12 \mathrm{~h}$ after onset of the dark phase. Analysis of the upstream sequence of EYA3 has identified three conserved E-boxes in the promoter, implying that it may be regulated by CLOCK and BMAL; in fact CLOCK and BMAL have an additive effect on activation of EYA3 promoter constructs (Dardente et al. 2010). Although the mechanisms of dawn-activation and melatonin-mediated suppression remain to be fully identified, the pattern of induction is compatible with a role for circadian changes in cAMP activation. A current model is that EYA3 may be regulated both by circadian E-box and CREB site activation, in a manner similar to that for the dawn-activated circadian clock gene PER1. Thus, in the PT, the melatonin signal sets the phase of the circadian rhythm. On SD, continued secretion of melatonin coincides with the endogenous circadian-driven rise in EYA3 $12 \mathrm{~h}$ after melatonin onset, and EYA expression is greatly reduced due to the repression of cAMP. The system becomes de-repressed in response to long photoperiods, since the EYA3 phase is now at dawn, allowing full activation by cAMP. In this way, a circadian-regulated cycle, initiated by melatonin, drives a camp-responsive target.

The original discovery of a Per 1 transcript in the PT of mice (Sun et al. 1997) stimulated interest in the role that melatonin might play in the regulation of PT function. Initial studies in seasonal hamsters revealed that Per1 and Icer (Crem) (the inducible cyclic AMP early repressor) are strongly induced in the early photophase, following the decline in melatonin (Messager et al. 1999). The amplitude of this response is strongly photoperiod-regulated, with lowered amplitudes in response to SD. This photoperiodic effect is also seen in Siberian hamsters, and to a lesser extent in sheep (Lincoln et al. 2002, Johnston et al. 2005). In Siberian hamsters, it carries through to changes in PER1 protein expression (Nuesslein-Hildesheim et al. 2000). These features have been explored more extensively in sheep, in which transcript profiling for the key transcriptional repressors PERIOD (PER1 and PER2) and CRYPTOCHROME (CRY1 and CRY2) were compared with the expression of the activators CLOCK and BMAL1 (Lincoln et al. 2002). The PER1 transcript is closely phaselocked to the early photophase. In contrast, CRY1 is induced by melatonin (Dardente et al. 2003) such that its phase tracks dark onset (Lincoln et al. 2002, Dupré et al. 2008). As a consequence, the relative phasing of these two interacting components changes with photoperiod, with a relatively short PER-CRY interval with SDs, and an extended interval in response to long photoperiods (Fig. 5).

\section{Coincidence timing models: Bünning and Pittendrigh revisited}

Changes in the coincidence of PER and CRY with photoperiod have led to the proposition that these genes might operate as an internal coincidence timer within the PT (Lincoln et al. 2002, 2003; Fig. 5). The close coincidence of PER and CRY during SD is consistent with this model, since these transcriptional repressors have been proposed to act as a dimeric pair, suppressing CLOCK and BMAL1 expression during the circadian cycle (Reppert \& Weaver 2001, 2002). This might therefore result in altered regulation of E-box-controlled genes, for which EYA3 remains a candidate. More recently, it has become apparent that CRY proteins act as the dominant transcriptional repressor of CLOCK/BMAL1-mediated E-box transcription (Ye et al. 2011), and PER proteins may gate the timing of CRY nuclear accumulation. A recent study has mapped the CRY 'cistrome' for hepatic target genes using ChIP-seq (Koike et al. 2012), showing it acts on multiple targets and that only a minority of the CRYPTOCHROME-binding sites are recognised 'clock' elements bound to BMAL1/CLOCK heterodimers. The majority of CRY sites for instance overlap with recognition sequences for nuclear hormone receptors. CRY is therefore a prime candidate for the molecule responsible for synchronising the melatonin-driven oscillation in

Published by Bioscientifica Ltd 
response to photoperiod in this endocrine tissue, but we know little of its action on target genes in the PT.

Although the internal coincidence model remains to be rigorously tested, the TSH response in Per2 knockout mice has been measured, showing a robust photoperiodic response by Tsh $\beta$, Dio 2 and Dio3 genes (Ikegami et al. 2013). Deletion of Per2 altered expression of other PTclock gene components, but importantly many of these remained rhythmic - albeit at lower amplitude. A prediction of an internal coincidence PER-CRY timer is that with very long photoperiods, the phasing of PER and CRY would become closer, and similar to the pattern observed with SD, perhaps eliciting a physiological response similar to that under SD conditions. This has been explored using sheep as a model (Wagner et al. 2008), and here surprisingly, transfer to ultra-long periods of illlumination ( 20 and $22 \mathrm{~h}$ of light/day) elicits responses markedly similar to those under SD conditions, with suppression of TSH $\beta$. CRY remained locked to the onset of the short-duration melatonin signal, and PER1 after the onset of illumination. In these circumstances, with a closely associated PER/CRY rhythm, PER1 re-establishes low amplitude SD-like PER1 expression in the early photophase (Hong \& Stetson 1986, Hong et al. 1986).

In the PT, CRY is the prime candidate for, setting the phase of the PT cycle, driven by melatonin. Typically, CRY1 mRNA levels in the PT rise over a period $2 \mathrm{~h}$ or more in response to melatonin (Dupré et al. 2008, West et al. 2013). There are sites for the immediate early gene EGR 1 on the $C R Y$ promoter, and the EGR1-RE is acutely regulated by melatonin, but studies in cell lines indicate that EGR1 may act as a repressor rather than an activator of $C R Y$ (Fustin et al. 2009). Using RNA-seq to define dynamic changes in the melatonin-regulated PT transcriptome, we have identified a cluster of 'early-response' genes, rising sharply within $1.5 \mathrm{~h}$ (West et al. 2013). Within this, a transcription factor, NPAS4 (also known as neuronal $\mathrm{X}$ factor $(N X F)$ ), exhibits an increase of 30- to 50-fold. NPAS4 appears to act as a key regulator of $C R Y 1$ (Fig. 5; West et al. 2013). In vitro, NPAS4 forms functional dimers with basic helix loop helixPAS domain co-factors aryl hydrocarbon receptor nuclear translocator (ARNT), ARNT2, and ARNTL (BMAL1), transactivating both $C R Y 1$ and also the melatonin-induced NAMPT promoter. The transactivation by NPAS4-ARNT appears to be co-dependent upon two conserved central midline elements within the CRY1 promoter. NPAS4 may therefore act as a key immediate early-response gene in the ovine PT, driving molecular responses to melatonin and setting the phase of the PT oscillation (Fig. 5).

\section{The PT as an integrator of seasonal hormone rhythms: the prolactin read-out}

While some of the mechanisms mediating TSH regulation of TH metabolism have been mapped out, we have much less information on the seasonal control of prolactin. The hormone provides a robust read-out of a LD response in both birds and mammals (Fig. 1), and one hypothesis in mammals could involve clock-regulated changes in the classical inhibitory input from the hypothalamus to the pituitary via dopamine. Current evidence strongly indicates that this is not the case, and that instead the primary mechanism probably involves an intra-pituitary circuit and the PT. Surgical disconnection of the pituitary from the hypothalamus (hypothalamic-pituitary disconnection (HPD)) in sheep spares the pituitary and its blood supply but abrogates the neuronal input, leading to reproductive collapse due to loss of GNRH neuronal input, but remarkably the seasonal control of prolactin regulation remains robustly photoperiodic (Lincoln \& Clarke 1994). These HPD sheep maintained for long periods with constant artificial LD lighting signals exhibit long-term circannual changes in prolactin secretion, but this depends on a normal LD-like melatonin signal (Lincoln et al. 2006). Therefore, the photoperiodic readout is necessary for the generation of long-term oscillations - the circannual clock. This focuses attention on the PT as both an integrator of the seasonal signal, via TH regulation, and in addition as a paracrine regulator of other pituitary hormone pathways, including lactotroph function.

This concept has been further advanced by showing that the ovine PT secretes a low-molecular-weight prolactin-regulating peptide of $<1 \mathrm{kDa}$ - which they termed 'tuberalin' (Morgan et al. 1996). In this model, tuberalin acts via an intra-pituitary circuit to control prolactin secretion. A number of groups, including ours, have sought a candidate tuberalin (Dupré et al. 2010). In sheep, the tachykinin 1 (TAC1) gene is sharply upregulated by LD signals in the PT, and from this, neurokinin A (NKA) now emerges as a strong candidate for driving seasonal prolactin secretion (Dupré et al. 2010). NKA and other proposed candidates (2-arachidonoyl glycerol (Yasuo \& Korf 2011)) are likely to act on intermediate cell types, as the key receptors for NKA (NK1, NK2 and NK3R) in the sheep PD are not observed in cells expressing PRL (lactotrophs) (Dupré et al. 2010). This indicates the involvement of indirect pathways, perhaps via FS cells, which do express neurokinin receptors.

In both hamsters and sheep, refractory responses to long-term fixed photoperiods lead to altered endocrine

Published by Bioscientifica Ltd 
output, but these are known not to be driven by altered melatonin signals, which remains reflective of the prevailing photoperiod. What role might the local PT circadian clockwork play? In hamsters maintained for long periods with inhibitory SD signals, the refractory PT maintains a robust clock gene rhythm similar to that under SD conditions, reflective of the melatonin cycle, but remarkably, the production of the PT-specific prolactin releasing signal(s) reverts in such animals to a phenotype resembling that under $\mathrm{LD}$ conditions (Johnston et al. 2003). The persistence of a photoperiod-regulated PT clock gene rhythm in refractory animals has also been confirmed in sheep (Lincoln et al. 2005). We do not know what circadian interval-timing mechanisms are involved in prolactin regulation, but clearly EYA3 must be considered as a candidate. A prediction would be that the expression of EYA3 might alter in refractory states, 'breaking' from the prevailing photoperiod signal. Such mechanisms were never considered in the early formulations of photoperiodic models of Bünning and Pittendrigh, but one process that could be involved is epigenetic methylation-based changes, currently under investigation in our laboratories. In this regard, it is important to note that the refractory hamster model has revealed a role for epigenetic regulation of Dio3 (Stevenson \& Prendergast 2013). In sheep, there is a spontaneous decline in $\mathrm{DIO} 2$ and increase in $\mathrm{DIO} 3$ in animals held long term on LDs (LD-refractory), correlating with a corresponding decline in TSH $\beta$ expression in the neighbouring PT (Sáenz de Miera et al. 2013). Thus, the deiodinase signalling system is capable of spontaneous reversion in refractory animals.

We are still a long way from understanding how the circannual rhythm may be generated, and the topic has been recently reviewed (Dardente 2012), including the interesting hypothesis that one underpinning mechanism may involve seasonal histogenesis as a longterm regenerative process (Hazlerigg \& Lincoln 2011). One feature is, however, however clear. In seasonal mammals, some of what we have understood from classical endocrinology needs to be revised in view of the new central role that the PT now plays. It is clearly an integrator of the circadian melatonin signal, driving hypothalamic circuits and, via a local paracrine signal, prolactin responses. In addition, the multiple pathways that control metabolic responses to photoperiod may be similarly controlled (Barrett \& Bolborea 2012). The PT is also a prime candidate as a site for the generation of long-term circannual oscillations.

\section{Conserved pathways and evolutionarily ancient circuits}

There are remarkable parallels between the mechanisms employed to time seasonal responses in birds and mammals, with both groups depending on TSH activation and a deiodinase control (Yoshimura 2013). Recent studies have yielded results indicating that the TSH system may operate as a conserved function in all vertebrates (Nakane et al. 2013). Fish (salmon, Oncorhynchus masou masou) lack an anatomically distinctive PT, but do possess a specialised circumventricular organ, the saccus vasculosus (SV), in the caudal hypothalamus of many jawed fish, which has long been known to serve as a secretory organ. A photoperiodic response in $\mathrm{Tsh} \beta$ and Dio2 protein levels in the SV of salmon was observed (Nakane et al. 2013), which remarkably can be recapitulated in culture by exposure to artificial lighting cycles. The SV expresses a number of opsin proteins, and removal of the SV blocks photoperiodic responses in salmon. This indicates that the TSH pathway may be well over 350 million years old, and pre-date the evolution of distinctive pituitary structures such as the PT in higher vertebrate lineages. There may indeed be links over a longer time scale. Seasonal timing is remarkably precise in many organisms, and in marine corals spawning is tightly synchronised to time of year. The eya gene in corals is tightly regulated by photoperiod (Brady et al. 2011). This raises the exciting prospect that the most ancient seasonal timers may include transcription factors, which were subsequently co-opted to drive a specific hormone-regulating pathway in vertebrates.

\section{Common design principles with plant seasonal interval timers}

The original concept of the external coincidence model of Bünning provides a crucial framework for research into the underlying genetic mechanisms driving seasonal timing. These concepts are more advanced in plants, where there are some remarkable common design principles involved (Fig. 6). The transition from vegetative to reproductive growth in plants is controlled by day length which is perceived in leaves and induces a systemic signal, called 'florigen', that moves through the vascular system to the shoot apex, resulting in flowering (Turck et al. 2008). The day length measurement mechanism in Arabidopsis thaliana is through the circadian regulation of the transcription factor CONSTANS (CO) by GI-FKF1, which is in turn controlled by

Published by Bioscientifica Ltd 
Seasonal mammal (sheep)

\section{External coincidence}
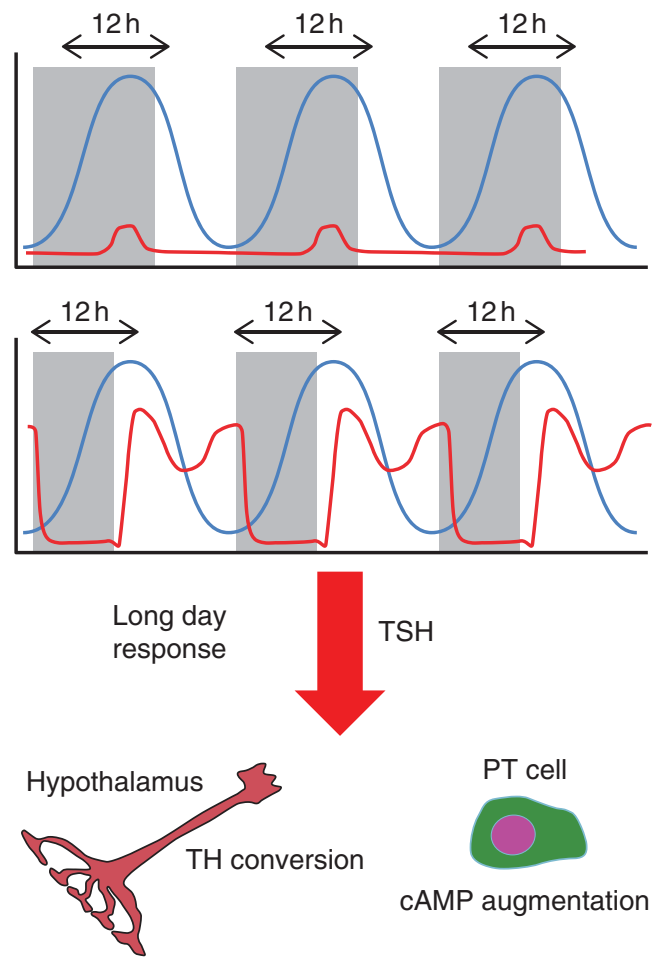

$222: 2$

\section{Figure 6}

Comparison of seasonal timing by photoperiod in mammals and plants. The left panel shows a current model for an external coincidence Eya3 timer in a mammal (sheep). The blue line represents the circadian clock oscillating over a day. The grey boxes show the period of darkness, with the top graph showing a short day and the bottom a long day (LD). The red line represents EYA3 expression. In this model, EYA3 rises $12 \mathrm{~h}$ after dark onset, but is suppressed by melatonin with short photoperiods. Thus the 'critical' day length for activation of a LD repertoire occurs at $12 \mathrm{~h}$ light or more. Changes in the internal coincidence of clock genes with the onset and offset of light are proposed to drive EYA3 expression, activating expression in response to LD signalling in adjacent hypothalamic

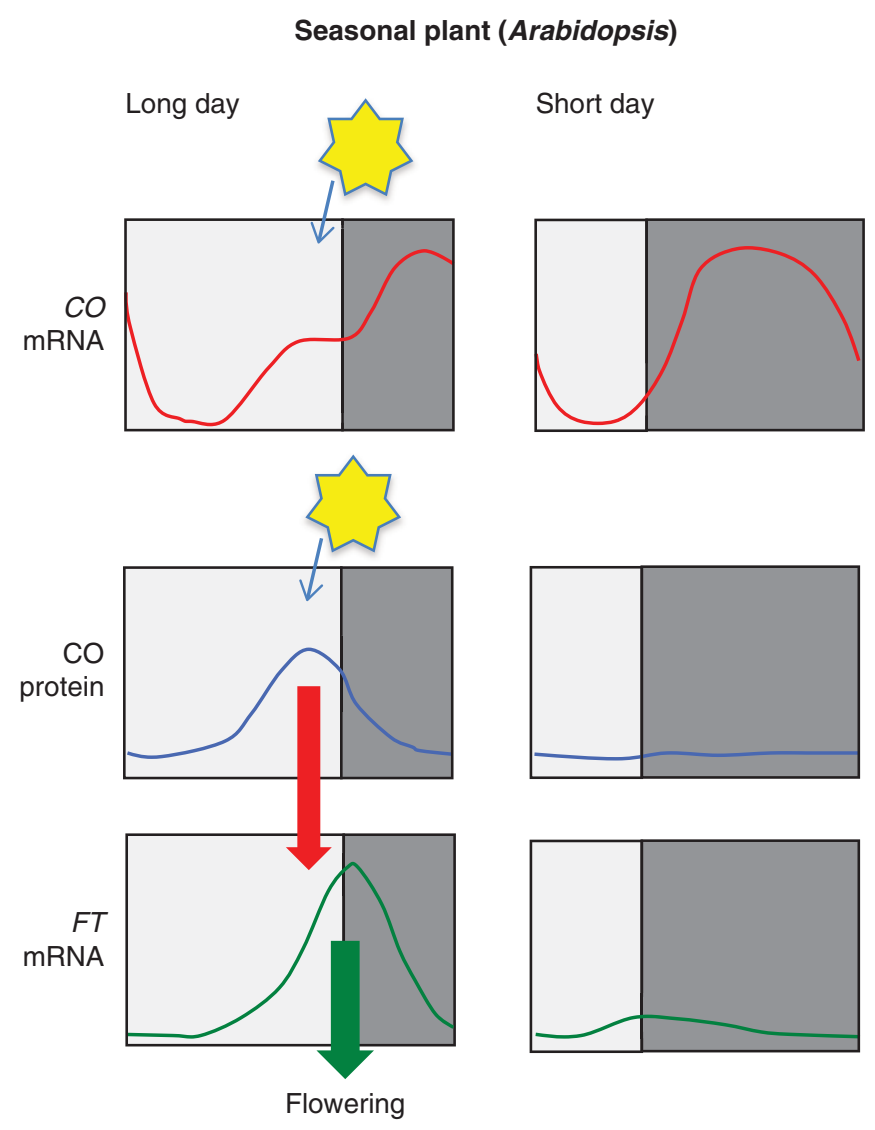

structures. Thus, seasonal timing may operate as a combination of both external and internal coincident timing processes. The right panel shows a similar coincidence timing model in a seasonal plant. Constans (CO) mRNA expression is under circadian control and modulated by season (red line). However, CO protein is unstable and degraded by dark exposure in plants. The protein signal can only be expressed if light is coincident with its expression. LD-activated CO then drives $F T$ expression, resulting in flowering. On SD, the CO/FT system is suppressed. In both plants and animals, the key upstream activator is dark-suppressed and is released only when the phase of the internal cycle coincides with light. Data on plants were adapted from Imaizumi \& Kay (2006). the CRY/PER equivalents in plants (Imaizumi \& Kay 2006). CO protein expression is tightly linked to the light phase and the protein actively degraded in darkness, and as a consequence, on SDs the protein is not expressed and flowering is inhibited. It is only when light is coincident with the expression of $\mathrm{CO}$ that the protein can be expressed - a classical Bünning model.

This looks remarkably like the EYA3-TSH system. EYA3 transcription is acutely inhibited by melatonin and its levels only rise if light is co-incident with a phase some $12 \mathrm{~h}$ after dark onset. Both EYA3 and CO activate proteins that themselves act on distal targets, and it is within these target sites that we now know that other epigenetic methylation-based processes may occur, e.g. vernalisation in plants (Angel et al. 2011). This vernalisation process operates as a 'salt-and-pepper' model, gradually switching individual cells into a changed state. This type of 'binary' on-off signalling is now a recognised feature of stochastic control, driving pituitary gene transcription (Lionnet \& Singer 2012), and is well described for prolactin (Featherstone et al. 2011, 2012). We believe that these mechanisms may underpin the long and sustained changes we have observed in EYA3 activation over a period of weeks following LD stimulation. 


\section{Relevance to human pathobiology}

Despite there being little evidence for a seasonal response in the human pituitary gland, new insights into mechanisms that underlie seasonal re-programming may prove to be important for understanding pituitary pathophysiology in humans. In the human PD, many pituitary adenomas are thought to be of gonadotroph origin. Thus the mechanisms that control the programming of these cell types during seasonal switching may turn out to have significant links to the genetic programmes implicated in development or progression of pituitary adenoma. Examples of genes regulated by melatonin in the PT include epigenetic regulators such as GADD45 r (Schäfer 2013, West et al. 2013) which have been implicated in some gonadotroph adenomas in man (Zhang et al. 2002, Bahar et al. 2004, Michaelis et al. 2011). It remains to be established to what extent epigenetic reprogramming mechanisms overlap between seasonal responses in the PT and hyperplasia or adenoma formation in the human pituitary.

\section{Conclusions}

The core message evolving from the recent wave of research into the genetic mechanisms driving biological timing is that the processes involved are incredibly ancient, frequently conserved, and obey a common set of rules. The more advanced modeling-based knowledge of the seasonal plant clock may provide key insights into vertebrate timing mechanisms, as we design experiments to search for the fundamental design principles involved in driving the rhythmic endocrinology of mammals. Finally, the recognition of the fascinating new role of the PT, as a retrograde regulator of hypothalamic TH action and also its paracrine control of anterior pituitary hormone secretion, now raises important questions regarding the role of the PT in the regulation of human pituitary function. This remains virtually unexplored.

\section{Declaration of interest}

The authors declare that there is no conflict of interest that could be perceived as prejudicing the impartiality of the review.

\section{Funding}

This work is supported by grants from the Biotechnology and Biological Sciences Research Council: BB/K003119/1 to A L and Julian Davis and BB/K000764/1 to David Burt and Alan McNeilly, University of Edinburgh.

\section{Acknowledgements}

Many past and current members of the Manchester/Edinburgh team have made contribution to discussions and offered advice, including Alan McNeilly, Julian Davis, David Burt, Sandrine Dupre, Le Yu, Ben Saer, Katarzyna Miedzinska, Bob Paton and Alex West. In addition, the authors thank David Hazlerigg (University of Tromso, Norway), Hughes Dardente (INRA, Tours, France), Gerald Lincoln (University of Edinburgh), Helen Christian (University of Oxford) and Takashi Yoshimura (University of Nagoya, Japan) for many helpful discussions and advice over the past years. They thank Eric Bittman, Bill Schwartz, Andrew Millar and David Bechtold for helpful comments on earlier drafts. They also thank the staff at the Marshall Building, Roslin, Edinburgh for expert care of their research animals.

\section{Footnote}

This review is based on the 2014 Society for Endocrinology Medal Lecture, presented by Dr Andrew Loudon at the Society for Endocrinology BES 2014, Liverpool, UK.

\section{References}

Akimoto M, Nishimaki T, Arai Y, Uchinuma E, Yamauchi H \& Kameda Y 2010 Hes1 regulates formations of the hypophyseal pars tuberalis and the hypothalamus. Cell and Tissue Research 340 509-521. (doi:10.1007/ s00441-010-0951-2)

Akmayev IG \& Fidelina OV 1974 Morphological aspects of the hypothalamic-hypophyseal system. V. The tanycytes: their relation to the hypophyseal adrenocorticotrophic function. An enzymehistochemical study. Cell and Tissue Research 152 403-410. (doi:10.1007/BF00223957)

Anderson GM \& Barrell GK 1998 Pulsatile luteinizing hormone secretion in the ovariectomized, thyroidectomized red deer hind following treatment with dopaminergic and opioidergic agonists and antagonists. Biology of Reproduction 59 960-968. (doi:10.1095/biolreprod59.4.960)

Anderson G, Hardy SL, Valent M, Billings HJ, Connors JM \& Goodman RL 2003 Evidence that thyroid hormones act in the ventromedial preoptic area and the premammillary region of the brain to allow the termination of the breeding season in the ewe. Endocrinology 144 2892-2901. (doi:10.1210/en.2003-0322)

Angel A, Song J, Dean C \& Howard M 2011 A polycomb-based switch underlying quantitative epigenetic memory. Nature 476 105-108. (doi:10.1038/nature10241)

Bahar A, Bicknell JE, Simpson DJ, Clayton RN \& Farrell WE 2004 Loss of expression of the growth inhibitory gene $G A D D 45 \gamma$, in human pituitary adenomas, is associated with CpG island methylation. Oncogene 23 936-944. (doi:10.1038/sj.onc.1207193)

Barrell GK, Moenter SM, Caraty A \& Karsch FJ 1992 Seasonal changes of gonadotropin-releasing hormone secretion in the ewe. Biology of Reproduction 46 1130-1135. (doi:10.1095/biolreprod46.6.1130)

Barrett P \& Bolborea M 2012 Molecular pathways involved in seasonal body weight and reproductive responses governed by melatonin. Journal of Pineal Research 52 376-388. (doi:10.1111/j.1600-079X.2011.00963.x)

Barrett P, Schuster C, Mercer J \& Morgan PJ 2003a Sensitization: a mechanism for melatonin action in the pars tuberalis. Journal of Neuroendocrinology $\mathbf{1 5}$ 415-421. (doi:10.1046/j.1365-2826.2003.00988.x)

Barrett P, Conway S \& Morgan PJ 2003b Digging deep - structure-function relationships in the melatonin receptor family. Journal of Pineal Research 35 221-230. (doi:10.1034/j.1600-079X.2003.00090.x)

Barrett P, Ivanova E, Graham ES, Ross AW, Wilson D, Plé H, Mercer JG, Ebling FJ, Schuhler S, Dupré SM et al. 2006 Photoperiodic regulation of cellular retinol binding protein, CRBP1 [corrected] and nestin in tanycytes of

Published by Bioscientifica Ltd 
the third ventricle ependymal layer of the Siberian hamster. Journal of Endocrinology 191 687-698. (doi:10.1677/joe.1.06929)

Barrett P, Ebling FJ, Schuhler S, Wilson D, Ross AW, Warner A, Jethwa P, Boelen A, Visser TJ, Ozanne DM et al. 2007 Hypothalamic thyroid hormone catabolism acts as a gatekeeper for the seasonal control of body weight and reproduction. Endocrinology 148 3608-3617. (doi:10.1210/en.2007-0316)

Bartness TJ, Goldman BD \& Bittman EL 1991 SCN lesions block responses to systemic melatonin infusions in Siberian hamsters. American Journal of Physiology 260 R102-R112.

Bechtold DA, Sidibe A, Saer BR, Li J, Hand LE, Ivanova EA, Darras VM, Dam J, Jockers R, Luckman SM et al. 2012 A role for the melatonin-related receptor GPR50 in leptin signaling, adaptive thermogenesis, and torpor. Current Biology 22 70-77. (doi:10.1016/j.cub.2011.11.043)

Benoit J 1936 Role de la thyroide dans la gonado-stimulation par lumiere artificielle chez le canard domestique. Comptes Rendus Societe de Biologie Paris 123 243-246.

Berson DM, Dunn FA \& Takao M 2002 Phototransduction by retinal ganglion cells that set the circadian clock. Science 295 1070-1073. (doi:10.1126/science.1067262)

Billings HJ, Viguié C, Karsch FJ, Goodman RL, Connors JM \& Anderson GM 2002 Temporal requirements of thyroid hormones for seasonal changes in LH secretion. Endocrinology 143 2618-2625. (doi:10.1210/ endo.143.7.8924)

Bittman EL, Dempsey RJ \& Karsch FJ 1983 Pineal melatonin secretion drives the reproductive response to daylength in the ewe. Endocrinology 113 2276-2283. (doi:10.1210/endo-113-6-2276)

Bockmann J, Böckers TM, Winter C, Wittkowski W, Winterhoff H, Deufel T \& Kreutz MR 1997 Thyrotropin expression in hypophyseal pars tuberalis-specific cells is 3,5,3'-triiodothyronine, thyrotropin-releasing hormone, and Pit-1 independent. Endocrinology 138 1019-1028. (doi:10.1210/endo.138.3.5007)

Bolborea M \& Dale N 2013 Hypothalamic tanycytes: potential roles in the control of feeding and energy balance. Trends in Neurosciences 36 91-100. (doi:10.1016/j.tins.2012.12.008)

Brady AK, Snyder KA \& Vize PD 2011 Circadian cycles of gene expression in the coral, Acropora millepora. PLoS ONE 6 e25072. (doi:10.1371/journal. pone.0025072)

Brinklow BR \& Loudon AS 1993 Evidence for a circannual rhythm of reproduction and prolactin secretion in a seasonally breeding macropodid marsupial, the Bennett's wallaby (Macropus rufogriseus rufogriseus). Journal of Reproduction and Fertility 98 625-630. (doi:10.1530/jrf.0.0980625)

Bronson FH 1995 Seasonal variation in human reproduction: environmental factors. Quarterly Review of Biology 70 141-164. (doi:10.1086/ 418980)

Brown TM \& Piggins HD 2009 Spatiotemporal heterogeneity in the electrical activity of suprachiasmatic nuclei neurons and their response to photoperiod. Journal of Biological Rhythms 24 44-54. (doi:10.1177/ 0748730408327918)

Bünning E 1936 Die endogene Tagesperiodik als Grundlage der photoperiodischen Reaktion. Berichte der Deutschen Botanischen Gesellschaft 54 590-608.

Carter DS \& Goldman BD 1983 Antigonadal effects of timed melatonin infusion in pinealectomized male Djungarian hamsters (Phodopus sungorus sungorus): duration is the critical parameter. Endocrinology $\mathbf{1 1 3}$ 1261-1267. (doi:10.1210/endo-113-4-1261)

Dardente H 2012 Melatonin-dependent timing of seasonal reproduction by the pars tuberalis: pivotal roles for long daylengths and thyroid hormones. Journal of Neuroendocrinology 24 249-266. (doi:10.1111/j. 1365-2826.2011.02250.x)

Dardente H, Klosen P, Pévet P \& Masson-Pévet M 2003 MT1 melatonin receptor mRNA expressing cells in the pars tuberalis of the European hamster: effect of photoperiod. Journal of Neuroendocrinology 15 778-786. (doi:10.1046/j.1365-2826.2003.01060.x)
Dardente H, Wyse CA, Birnie MJ, Dupré SM, Loudon AS, Lincoln GA \& Hazlerigg DG 2010 A molecular switch for photoperiod responsiveness in mammals. Current Biology 20 2193-2198. (doi:10.1016/j.cub.2010.10.048)

Dardente H, Hazlerigg DG \& Ebling FJ 2014 Thyroid hormone and seasonal rhythmicity. Frontiers in Endocrinology 5 19. (doi:10.3389/fendo.2014. 00019)

Dawson A, King VM, Bentley GE \& Ball GF 2001 Photoperiodic control of seasonality in birds. Journal of Biological Rhythms 16 365-380. (doi:10.1177/074873001129002079)

Deneubourg J-L, Destexhe A, Leloup J-C, Ebenhöh O \& Hazlerigg D 2013 Modelling a molecular calendar: the seasonal photoperiodic response in mammals. Chaos, Solitons, and Fractals 50 39-47. (doi:10.1016/j. chaos.2012.11.007)

Dufourny L, Levasseur A, Migaud M, Callebaut I, Pontarotti P, Malpaux B \& Monget P 2008 GPR50 is the mammalian ortholog of Mel1c: evidence of rapid evolution in mammals. BMC Evolutionary Biology 8105. (doi:10.1186/1471-2148-8-105)

Dupré SM, Burt DW, Talbot R, Downing A, Mouzaki D, Waddington D, Malpaux B, Davis JRE, Lincoln GA \& Loudon AS 2008 Identification of melatonin-regulated genes in the ovine pituitary pars tuberalis, a target site for seasonal hormone control. Endocrinology 149 5527-5539. (doi:10.1210/en.2008-0834)

Dupré SM, Miedzinska K, Duval CV, Yu L, Goodman RL, Lincoln GA, Davis JRE, McNeilly AS, Burt DD \& Loudon AS 2010 Identification of Eya3 and TAC1 as long-day signals in the sheep pituitary. Current Biology 20 829-835. (doi:10.1016/j.cub.2010.02.066)

Ebling FJ \& Barrett P 2008 The regulation of seasonal changes in food intake and body weight. Journal of Neuroendocrinology 20 827-833. (doi:10.1111/j.1365-2826.2008.01721.x)

Elliott JA, Stetson MH \& Menaker M 1972 Regulation of testis function in golden hamsters: a circadian clock measures photoperiodic time. Science 178 771-773. (doi:10.1126/science.178.4062.771)

Featherstone K, Harper CV, McNamara A, Semprini S, Spiller DG, McNeilly J, McNeilly AS, Mullins JJ, White MRH \& Davis JRE 2011 Pulsatile patterns of pituitary hormone gene expression change during development. Journal of Cell Science 124 3484-3491. (doi:10.1242/ jcs.088500)

Featherstone K, White MRH \& Davis JRE 2012 The prolactin gene: a paradigm of tissue-specific gene regulation with complex temporal transcription dynamics. Journal of Neuroendocrinology 24 977-990. (doi:10.1111/j.1365-2826.2012.02310.x)

Follett BK \& Nicholls TJ 1985 Influences of thyroidectomy and thyroxine replacement on photoperiodically controlled reproduction in quail. Journal of Endocrinology 107 211-221. (doi:10.1677/joe.0.1070211)

Follett BK \& Sharp PJ 1969 Circadian rhythmicity in photoperiodically induced gonadotrophin release and gonadal growth in the quail. Nature 223 968-971. (doi:10.1038/223968b0)

Follett BK, Mattocks PW \& Farner DS 1974 Circadian function in the photoperiodic induction of gonadotropin secretion in the whitecrowned sparrow, Zonotrichia leucophrys gambelii. PNAS 71 1666-1669. (doi:10.1073/pnas.71.5.1666)

Fustin JM, Dardente H, Wagner GC, Carter DA, Johnston JD, Lincoln GA \& Hazlerigg DG 2009 Egr1 involvement in evening gene regulation by melatonin. FASEB Journal 23 764-773. (doi:10.1096/fj.08-121467)

Von Gall C, Garabette ML, Kell CA, Frenzel S, Dehghani F, SchummDraeger P-M, Weaver DR, Korf H-W, Hastings MH \& Stehle JH 2002 Rhythmic gene expression in pituitary depends on heterologous sensitization by the neurohormone melatonin. Nature Neuroscience $\mathbf{5}$ 234-238. (doi:10.1038/nn806)

Goldman BD 2001 Mammalian photoperiodic system: formal properties and neuroendocrine mechanisms of photoperiodic time measurement. Journal of Biological Rhythms 16 283-301. (doi:10.1177/ 074873001129001980)

Goldman BD, Darrow JM \& Yogev L 1984 Effects of timed melatonin infusions on reproductive development in the Djungarian hamster

Published by Bioscientifica Ltd 
(Phodopus sungorus). Endocrinology 114 2074-2083. (doi:10.1210/ endo-114-6-2074)

Goodman RL, Legan SJ, Ryan KD, Foster DL \& Karsch FJ 1981 Importance of variations in behavioural and feedback actions of oestradiol to the control of seasonal breeding in the ewe. Journal of Endocrinology $\mathbf{8 9}$ 229-240. (doi:10.1677/joe.0.0890229)

Goodman RL, Bittman EL, Foster DL \& Karsch FJ 1982 Alterations in the control of luteinizing hormone pulse frequency underlie the seasonal variation in estradiol negative feedback in the ewe. Biology of Reproduction 27 580-589. (doi:10.1095/biolreprod27.3.580)

Grosse J, Maywood ES, Ebling FJ \& Hastings MH 1993 Testicular regression in pinealectomized Syrian hamsters following infusions of melatonin delivered on non-circadian schedules. Biology of Reproduction 49 666-674. (doi:10.1095/biolreprod49.4.666)

Gwinner E 1981 Circannual rhythms in animals and their photoperiodic synchronization. Die Naturwissenschaften 68 542-551. (doi:10.1007/ BF00401662)

Gwinner E \& Dittami J 1990 Endogenous reproductive rhythms in a tropical bird. Science 249 906-908. (doi:10.1126/science.249.4971.906)

Hamner WM 1963 Diurnal rhythm and photoperiodism in testicular recrudescence of the house finch. Science 142 1294-1295. (doi:10.1126/ science.142.3597.1294)

Hanon EA, Lincoln GA, Fustin J-M, Dardente H, Masson-Pévet M, Morgan PJ \& Hazlerigg DG 2008 Ancestral TSH mechanism signals summer in a photoperiodic mammal. Current Biology 18 1147-1152. (doi:10.1016/ j.cub.2008.06.076)

Hanon EA, Routledge K, Dardente H, Masson-Pévet M, Morgan PJ \& Hazlerigg DG 2010 Effect of photoperiod on the thyroid-stimulating hormone neuroendocrine system in the European hamster (Cricetus cricetus). Journal of Neuroendocrinology 22 51-55. (doi:10.1111/j. 1365-2826.2009.01937.x)

Hattar S, Liao HW, Takao M, Berson DM \& Yau KW 2002 Melanopsincontaining retinal ganglion cells: architecture, projections, and intrinsic photosensitivity. Science 295 1065-1070. (doi:10.1126/ science.1069609)

Hazlerigg DG \& Lincoln GA 2011 Hypothesis: cyclical histogenesis is the basis of circannual timing. Journal of Biological Rhythms 26 471-485. (doi:10.1177/0748730411420812)

Hazlerigg DG \& Loudon A 2008 New insights into ancient seasonal life timers. Current Biology 18 R795-R804. (doi:10.1016/j.cub.2008.07.040)

Hazlerigg DG, Morgan PJ, Lawson W \& Hastings MH 1991 Melatonin inhibits the activation of cyclic AMP-dependent protein kinase in cultured pars tuberalis cells from ovine pituitary. Journal of Neuroendocrinology 3 597-603. (doi:10.1111/j.1365-2826.1991.tb00324.x)

Hazlerigg DG, Gonzalez-Brito A, Lawson W, Hastings MH \& Morgan PJ 1993 Prolonged exposure to melatonin leads to time-dependent sensitization of adenylate cyclase and downregulates melatonin receptors in pars tuberalis cells from ovine pituitary. Endocrinology 132 285-292. (doi:10.1210/endo.132.1.7678217)

Hazlerigg DG, Morgan PJ \& Messager S 2001 Decoding photoperiodic time and melatonin in mammals: what can we learn from the pars tuberalis? Journal of Biological Rhythms 16 326-335. (doi:10.1177/ 074873001129002042)

Hazlerigg DG, Ebling FJ \& Johnston JD 2005 Photoperiod differentially regulates gene expression rhythms in the rostral and caudal SCN. Current Biology 15 R449-R450. (doi:10.1016/j.cub.2005.06.010)

Henson JR, Carter SN \& Freeman DA 2013 Exogenous $\mathrm{T}_{3}$ elicits long day-like alterations in testis size and the RFamides kisspeptin and gonadotropin-inhibitory hormone in short-day Siberian hamsters. Journal of Biological Rhythms 28 193-200. (doi:10.1177/ 0748730413487974)

Herwig A, Petri I \& Barrett P 2012 Hypothalamic gene expression rapidly changes in response to photoperiod in juvenile Siberian hamsters (Phodopus sungorus). Journal of Neuroendocrinology 24 991-998. (doi:10.1111/j.1365-2826.2012.02324.x)
Heyland A, Hodin J \& Reitzel AM 2005 Hormone signaling in evolution and development: a non-model system approach. BioEssays 27 64-75. (doi:10.1002/bies.20136)

Hinds L \& Loudon A 1997 Mechanisms of seasonality in marsupials: a comparative review. In Marsupial Biology - Recent Research, New Perspectives, pp 41-70. Eds NR Saunders \& LA Hinds. Sydney: University of New South Wales Press.

Hoffman RA \& Reiter RJ 1965 Pineal gland: influence on gonads of male hamsters. Science 148 1609-1611. (doi:10.1126/science.148.3677.1609)

Hong SM \& Stetson MH 1986 Functional maturation of the gonads of Turkish hamsters under various photoperiods. Biology of Reproduction 35 858-862. (doi:10.1095/biolreprod35.4.858)

Hong SM, Rollag MD \& Stetson MH 1986 Maintenance of testicular function in Turkish hamsters: interaction of photoperiod and the pineal gland. Biology of Reproduction 34 527-531. (doi:10.1095/ biolreprod34.3.527)

Ikegami K, Iigo M \& Yoshimura T 2013 Circadian clock gene Per2 is not necessary for the photoperiodic response in mice. PLOS ONE $\mathbf{8}$ e58482. (doi:10.1371/journal.pone.0058482)

Imaizumi T \& Kay SA 2006 Photoperiodic control of flowering: not only by coincidence. Trends in Plant Science 11 550-558. (doi:10.1016/j.tplants. 2006.09.004)

Inagaki N, Honma S, Ono D, Tanahashi Y \& Honma K 2007 Separate oscillating cell groups in mouse suprachiasmatic nucleus couple photoperiodically to the onset and end of daily activity. PNAS 104 7664-7669. (doi:10.1073/pnas.0607713104)

Jemc J \& Rebay I 2007 Identification of transcriptional targets of the dualfunction transcription factor/phosphatase eyes absent. Developmental Biology 310 416-429. (doi:10.1016/j.ydbio.2007.07.024)

Johnston JD, Cagampang FR, Stirland JA, Carr AJ, White MR, Davis JR \& Loudon AS 2003 Evidence for an endogenous per1- and ICER-independent seasonal timer in the hamster pituitary gland. FASEB Journal 17 810-815. (doi:10.1096/fj.02-0837com)

Johnston JD, Ebling FJ \& Hazlerigg DG 2005 Photoperiod regulates multiple gene expression in the suprachiasmatic nuclei and pars tuberalis of the Siberian hamster (Phodopus sungorus). European Journal of Neuroscience 21 2967-2974. (doi:10.1111/j.1460-9568. 2005.04148.x)

Johnston JD, Klosen P, Barrett P \& Hazlerigg DG 2006 Regulation of MT melatonin receptor expression in the foetal rat pituitary. Journal of Neuroendocrinology 18 50-56. (doi:10.1111/j.1365-2826.2005.01389.x)

Karsch FJ \& Moenter SM 1990 Neuroendocrine regulation of seasonal breeding cycles in the ewe. Journal of Experimental Zoology. Supplement 4 17-21. (doi:10.1002/jez.1402560405)

Klosen P, Bienvenu C, Demarteau O, Dardente H, Guerrero H, Pévet P \& Masson-Pévet M 2002 The mt 1 melatonin receptor and ROR $\beta$ receptor are co-localized in specific TSH-immunoreactive cells in the pars tuberalis of the rat pituitary. Journal of Histochemistry and Cytochemistry 50 1647-1657. (doi:10.1177/002215540205001209)

Klosen P, Sébert M-E, Rasri K, Laran-Chich M-P \& Simonneaux V 2013 TSH restores a summer phenotype in photoinhibited mammals via the RF-amides RFRP3 and kisspeptin. FASEB Journal 27 2677-2686. (doi:10.1096/fj.13-229559)

Koike N, Yoo S-H, Huang H-C, Kumar V, Lee C, Kim T-K \& Takahashi JS 2012 Transcriptional architecture and chromatin landscape of the core circadian clock in mammals. Science 338 349-354. (doi:10.1126/ science.1226339)

Korf HW, Schomerus C \& Stehle JH 1998 The pineal organ, its hormone melatonin, and the photoneuroendocrine system. Advances in Anatomy Embryology and Cell Biology 146 1-100.

Leitner C \& Bartness TJ 2011 An intact dorsomedial hypothalamic nucleus, but not the subzona incerta or reuniens nucleus, is necessary for short-day melatonin signal-induced responses in Siberian hamsters. Neuroendocrinology 93 29-39. (doi:10.1159/000320474)

Lincoln GA \& Clarke IJ 1994 Photoperiodically-lnduced cycles in the secretion of prolactin in hypothalamo-pituitary disconnected rams: 
evidence for translation of the melatonin signal in the pituitary gland. Journal of Neuroendocrinology 6 251-260. (doi:10.1111/j.1365-2826. 1994.tb00580.x)

Lincoln GA \& Short RV 1980 Seasonal breeding: nature's contraceptive. Recent Progress in Hormone Research 36 1-52.

Lincoln G, Messager S, Andersson H \& Hazlerigg D 2002 Temporal expression of seven clock genes in the suprachiasmatic nucleus and the pars tuberalis of the sheep: evidence for an internal coincidence timer. PNAS 99 13890-13895. (doi:10.1073/pnas.212517599)

Lincoln GA, Andersson H \& Loudon A 2003 Clock genes in calendar cells as the basis of annual timekeeping in mammals - a unifying hypothesis. Journal of Endocrinology 179 1-13. (doi:10.1677/joe.0.1790001)

Lincoln GA, Johnston JD, Andersson H, Wagner G \& Hazlerigg DG 2005 Photorefractoriness in mammals: dissociating a seasonal timer from the circadian-based photoperiod response. Endocrinology 146 3782-3790. (doi:10.1210/en.2005-0132)

Lincoln GA, Clarke IJ, Hut RA \& Hazlerigg DG 2006 Characterizing a mammalian circannual pacemaker. Science 314 1941-1944. (doi:10.1126/science.1132009)

Lionnet T \& Singer RH 2012 Transcription goes digital. EMBO Reports 13 313-321. (doi:10.1038/embor.2012.31)

Loudon AS \& Curlewis JD 1988 Cycles of antler and testicular growth in an aseasonal tropical deer (Axis axis). Journal of Reproduction and Fertility $\mathbf{8 3}$ 729-738. (doi:10.1530/jrf.0.0830729)

Loudon AS, Ihara N \& Menaker M 1998 Effects of a circadian mutation on seasonality in Syrian hamsters (Mesocricetus auratus). Proceedings. Biological Sciences 265 517-521. (doi:10.1098/rspb.1998.0325)

Lowrey PL, Shimomura K, Antoch MP, Yamazaki S, Zemenides PD, Ralph MR, Menaker M \& Takahashi JS 2000 Positional syntenic cloning and functional characterization of the mammalian circadian mutation tau. Science 288 483-492. (doi:10.1126/science.288.5465.483)

Lu W, Meng QJ, Tyler NJ, Stokkan KA \& Loudon AS 2010 A circadian clock is not required in an arctic mammal. Current Biology 20 533-537. (doi:10.1016/j.cub.2010.01.042)

Lucas RJ \& Foster RG 1999 Neither functional rod photoreceptors nor rod or cone outer segments are required for the photic inhibition of pineal melatonin. Endocrinology 140 1520-1524. (doi:/10.1210/endo.140. 4.6672)

Lucas RJ, Stirland JA, Darrow JM, Menaker M \& Loudon AS 1999 Free running circadian rhythms of melatonin, luteinizing hormone, and cortisol in Syrian hamsters bearing the circadian tau mutation. Endocrinology 140 758-764. (doi:10.1210/endo.140.2.6538)

Lucas RJ, Hattar S, Takao M, Berson DM, Foster RG \& Yau K-W 2003 Diminished pupillary light reflex at high irradiances in melanopsinknockout mice. Science 299 245-247. (doi:10.1126/science.1077293)

Masumoto K-H, Ukai-Tadenuma M, Kasukawa T, Nagano M, Uno KD, Tsujino K, Horikawa K, Shigeyoshi Y \& Ueda HR 2010 Acute induction of Eya3 by late-night light stimulation triggers TSH $\beta$ expression in photoperiodism. Current Biology 20 2199-2206. (doi:10.1016/j.cub. 2010.11.038)

Maywood ES, Buttery RC, Vance GH, Herbert J \& Hastings MH 1990 Gonadal responses of the male Syrian hamster to programmed infusions of melatonin are sensitive to signal duration and frequency but not to signal phase nor to lesions of the suprachiasmatic nuclei. Biology of Reproduction 43 174-182. (doi:10.1095/biolre$\operatorname{prod} 43.2 .174)$

Maywood ES, Grosse J, Lindsay JO, Karp JD, Powers JB, Ebling FJ, Herbert J \& Hastings MH 1992 The effect of signal frequency on the gonadal response of male Syrian hamsters to programmed melatonin infusions. Journal of Neuroendocrinology 4 37-44. (doi:10.1111/j.1365-2826.1992. tb00342.x)

Meijer JH, Thio B, Albus H, Schaap J \& Ruijs AC 1999 Functional absence of extraocular photoreception in hamster circadian rhythm entrainment. Brain Research 831 337-339. (doi:10.1016/S0006-8993(99)01509-7)

Meng Q-J, Logunova L, Maywood ES, Gallego M, Lebiecki J, Brown TM, Sládek M, Semikhodskii AS, Glossop NR, Piggins HD et al. 2008 Setting clock speed in mammals: the CK1 $\varepsilon$ tau mutation in mice accelerates circadian pacemakers by selectively destabilizing PERIOD proteins. Neuron 58 78-88. (doi:10.1016/j.neuron.2008.01.019)

Messager S, Ross AW, Barrett P \& Morgan PJ 1999 Decoding photoperiodic time through Per1 and ICER gene amplitude. PNAS 96 9938-9943. (doi:10.1073/pnas.96.17.9938)

Messager S, Garabette ML, Hastings MH \& Hazlerigg DG 2001 Tissuespecific abolition of Per 1 expression in the pars tuberalis by pinealectomy in the Syrian hamster. Neuroreport 12 579-582. (doi:10.1097/ 00001756-200103050-00029)

Michaelis KA, Knox AJ, Xu M, Kiseljak-Vassiliades K, Edwards MG, Geraci M, Kleinschmidt-DeMasters BK, Lillehei KO \& Wierman ME 2011 Identification of growth arrest and DNA-damage-inducible gene $\beta$ (GADD45 $\beta$ ) as a novel tumor suppressor in pituitary gonadotrope tumors. Endocrinology 152 3603-3613. (doi:10.1210/en.2011-0109)

Morgan PJ, Lawson W, Davidson G \& Howell HE 1989 Melatonin inhibits cyclic AMP production in cultured ovine pars tuberalis cells. Journal of Molecular Endocrinology 3 R5-R8. (doi:10.1677/jme.0.003R005)

Morgan PJ, Barrett P, Howell HE \& Helliwell R 1994 Melatonin receptors: localization, molecular pharmacology and physiological significance. Neurochemistry International 24 101-146. (doi:10.1016/01970186(94)90100-7)

Morgan PJ, Webster CA, Mercer JG, Ross AW, Hazlerigg DG, MacLean A \& Barrett P 1996 The ovine pars tuberalis secretes a factor(s) that regulates gene expression in both lactotropic and nonlactotropic pituitary cells. Endocrinology 137 4018-4026. (doi:10.1210/endo.137.9.8756579)

Murphy M, Jethwa PH, Warner A, Barrett P, Nilaweera KN, Brameld JM \& Ebling FJ 2012 Effects of manipulating hypothalamic triiodothyronine concentrations on seasonal body weight and torpor cycles in Siberian hamsters. Endocrinology 153 101-112. (doi:10.1210/en.2011-1249)

Naito E, Watanabe T, Tei H, Yoshimura T \& Ebihara S 2008 Reorganization of the suprachiasmatic nucleus coding for day length. Journal of Biological Rhythms 23 140-149. (doi:10.1177/0748730408314572)

Nakane Y, Ikegami K, Iigo M, Ono H, Takeda K, Takahashi D, Uesaka M, Kimijima M, Hashimoto R, Arai N et al. 2013 The saccus vasculosus of fish is a sensor of seasonal changes in day length. Nature Communications 4 2108. (doi:10.1038/ncomms3108)

Nakao N, Ono H, Yamamura T, Anraku T, Takagi T, Higashi K, Yasuo S, Katou Y, Kageyama S, Uno Y et al. 2008 Thyrotrophin in the pars tuberalis triggers photoperiodic response. Nature $\mathbf{4 5 2} 317-322$. (doi:10.1038/nature06738)

Nanda KK \& Hamner K 1958 Studies on the nature of the endogenous rhythm affecting photoperiodic response of Biloxi soybean. Botanical Gazette 120 14-28. (doi:10.1086/335992)

Nelson RJ \& Zucker I 1981 Photoperiodic control of reproduction in olfactory-bulbectomized rats. Neuroendocrinology 32 266-271. (doi:10.1159/000123171)

Nicholls TJ, Follett BK, Goldsmith AR \& Pearson H 1988 Possible homologies between photorefractoriness in sheep and birds: the effect of thyroidectomy on the length of the ewe's breeding season. Reproduction, Nutrition, Development 28 375-385. (doi:10.1051/ rnd:19880304)

Nuesslein-Hildesheim B, O'Brien JA, Ebling FJ, Maywood ES \& Hastings MH 2000 The circadian cycle of mPER clock gene products in the suprachiasmatic nucleus of the Siberian hamster encodes both daily and seasonal time. European Journal of Neuroscience 12 2856-2864. (doi:10.1046/j.1460-9568.2000.00173.x)

Oakley AE, Clifton DK \& Steiner RA 2009 Kisspeptin signaling in the brain. Endocrine Reviews 30 713-743. (doi:10.1210/er.2009-0005)

Ono H, Hoshino Y, Yasuo S, Watanabe M, Nakane Y, Murai A, Ebihara S, Korf H-W \& Yoshimura T 2008 Involvement of thyrotropin in photoperiodic signal transduction in mice. PNAS 105 18238-18242. (doi:10.1073/pnas.0808952105)

Panda S, Provencio I, Tu DC, Pires SS, Rollag MD, Castrucci AM, Pletcher MT, Sato TK, Wiltshire T, Andahazy M et al. 2003 Melanopsin is required 
for non-image-forming photic responses in blind mice. Science $\mathbf{3 0 1}$ 525-527. (doi:10.1126/science.1086179)

Paterson A, Chong NW, Brinklow BR, Loudon AS \& Sugden D 1992 Characterization of $2-\left[{ }^{125} \mathrm{I}\right]$ iodomelatonin binding sites in the brain of a marsupial, Bennett's wallaby (Macropus rufogriseus rufogriseus). Comparative Biochemistry and Physiology. Comparative Physiology 102 55-58. (doi:10.1016/0300-9629(92)90011-E)

Pittendrigh CS \& Minis DH 1964 The entrainment of circadian oscillations by light and their role as photoperiodic clocks. American Naturalist 98 261-299. (doi:10.1086/282327)

Post E \& Forchhammer MC 2008 Climate change reduces reproductive success of an arctic herbivore through trophic mismatch. Philosophical Transactions of the Royal Society of London. Series B, Biological Sciences 363 2369-2375. (doi:10.1098/rstb.2007.2207)

Prendergast BJ, Pyter LM, Kampf-Lassin A, Patel PN \& Stevenson TJ 2013 Rapid induction of hypothalamic iodothyronine deiodinase expression by photoperiod and melatonin in juvenile Siberian hamsters (Phodopus sungorus). Endocrinology 154 831-841. (doi:10.1210/en. 2012-1990)

Randall VA \& Ebling FJ 1991 Seasonal changes in human hair growth. British Journal of Dermatology 124 146-151. (doi:10.1111/j.1365-2133. 1991.tb00423.x)

Reiter RJ 1980 Photoperiod: its importance as an impeller of pineal and seasonal reproductive rhythms. International Journal of Biometeorology 24 57-63. (doi:10.1007/BF02245542)

Reppert SM 1997 Melatonin receptors: molecular biology of a new family of G protein-coupled receptors. Journal of Biological Rhythms 12 528-531. (doi:10.1177/074873049701200606)

Reppert SM \& Weaver DR 2001 Molecular analysis of mammalian circadian rhythms. Annual Review of Physiology 63 647-676. (doi:10.1146/ annurev.physiol.63.1.647)

Reppert SM \& Weaver DR 2002 Coordination of circadian timing in mammals. Nature 418 935-941. (doi:10.1038/nature00965)

Reppert SM, Weaver DR, Ebisawa T, Mahle CD \& Kolakowski LF 1996 Cloning of a melatonin-related receptor from human pituitary. FEBS Letters 386 219-224. (doi:10.1016/0014-5793(96)00437-1)

Revel FG, Saboureau M, Pévet P, Mikkelsen JD \& Simonneaux V 2006 Melatonin regulates type 2 deiodinase gene expression in the Syrian hamster. Endocrinology 147 4680-4687. (doi:10.1210/en.20060606)

Robinson JE, Radford HM \& Karsch FJ 1985 Seasonal changes in pulsatile luteinizing hormone (LH) secretion in the ewe: relationship of frequency of LH pulses to day length and response to estradiol negative feedback. Biology of Reproduction 33 324-334. (doi:10.1095/biolreprod33.2.324)

Rodríguez EM, Blázquez JL, Pastor FE, Peláez B, Peña P, Peruzzo B \& Amat P 2005 Hypothalamic tanycytes: a key component of brain-endocrine interaction. International Review of Cytology 247 89-164. (doi:10.1016/ S0074-7696(05)47003-5)

Ross AW, Helfer G, Russell L, Darras VM \& Morgan PJ 2011 Thyroid hormone signalling genes are regulated by photoperiod in the hypothalamus of F344 rats. PLOS ONE 6 e21351. (doi:10.1371/journal. pone.0021351)

Sáenz de Miera C, Hanon EA, Dardente H, Birnie M, Simonneaux V, Lincoln GA \& Hazlerigg DG 2013 Circannual variation in thyroid hormone deiodinases in a short-day breeder. Journal of Neuroendocrinology 25 412-421. (doi:10.1111/jne.12013)

Schäfer A 2013 Gadd45 proteins: key players of repair-mediated DNA demethylation. Advances in Experimental Medicine and Biology 793 35-50. (doi:10.1007/978-1-4614-8289-5_3)

Simonneaux V, Bur I, Ancel C, Ansel L \& Klosen P 2012 A kiss for daily and seasonal reproduction. Progress in Brain Research 199 423-437. (doi:10.1016/B978-0-444-59427-3.00024-1)

Simonneaux V, Ancel C, Poirel VJ \& Gauer F 2013 Kisspeptins and RFRP-3 act in concert to synchronize rodent reproduction with seasons. Frontiers in Neuroscience 7 22. (doi:10.3389/fnins.2013.00022)
Stevenson TJ \& Prendergast BJ 2013 Reversible DNA methylation regulates seasonal photoperiodic time measurement. PNAS 110 16651-16656. (doi:10.1073/pnas.1310643110)

Stirland JA, Hastings MH, Loudon AS \& Maywood ES 1996 The tau mutation in the Syrian hamster alters the photoperiodic responsiveness of the gonadal axis to melatonin signal frequency. Endocrinology 137 2183-2186. (doi:10.1210/endo.137.5.8612567)

Stokkan K-A \& Reiter RJ 1994 Melatonin rhythms in arctic urban residents. Journal of Pineal Research 16 33-36. (doi:10.1111/j.1600-079X.1994. tb00079.x)

Stokkan KA, van Oort BE, Tyler NJ \& Loudon AS 2007 Adaptations for life in the arctic: evidence that melatonin rhythms in reindeer are not driven by a circadian oscillator but remain acutely sensitive to environmental photoperiod. Journal of Pineal Research 43 289-293. (doi:10.1111/ j.1600-079X.2007.00476.x)

Sumová A, Jác M, Sládek M, Sauman I \& Illnerová H 2003 Clock gene daily profiles and their phase relationship in the rat suprachiasmatic nucleus are affected by photoperiod. Journal of Biological Rhythms 18 134-144. (doi:10.1177/0748730403251801)

Sun ZS, Albrecht U, Zhuchenko O, Bailey J, Eichele G \& Lee CC 1997 RIGUI, a putative mammalian ortholog of the Drosophila period gene. Cell $\mathbf{9 0}$ 1003-1011. (doi:10.1016/S0092-8674(00)80366-9)

Tadjuidje E \& Hegde RS 2013 The eyes absent proteins in development and disease. Cellular and Molecular Life Sciences 70 1897-1913. (doi:10.1007/ s00018-012-1144-9)

Tsutsui K, Ubuka T, Bentley GE \& Kriegsfeld LJ 2013 Review: Regulatory mechanisms of gonadotropin-inhibitory hormone $(\mathrm{GnIH})$ synthesis and release in photoperiodic animals. Frontiers in Neuroscience 760. (doi:10.3389/fnins.2013.00060)

Turck F, Fornara F \& Coupland G 2008 Regulation and identity of florigen: FLOWERING LOCUS T moves center stage. Annual Review of Plant Biology 59 573-594. (doi:10.1146/annurev.arplant.59. 032607.092755)

Wagner GC, Johnston JD, Clarke IJ, Lincoln GA \& Hazlerigg DG 2008 Redefining the limits of day length responsiveness in a seasonal mammal. Endocrinology 149 32-39. (doi:10.1210/en.20070658)

Weaver DR, Liu C \& Reppert SM 1996 Nature's knockout: the Mel1b receptor is not necessary for reproductive and circadian responses to melatonin in Siberian hamsters. Molecular Endocrinology 10 1478-1487. (doi:10.1210/mend.10.11.8923472)

Webster JR, Moenter SM, Woodfill CJ \& Karsch FJ $1991 a$ Role of the thyroid gland in seasonal reproduction. II. Thyroxine allows a season-specific suppression of gonadotropin secretion in sheep. Endocrinology 129 176-183. (doi:10.1210/endo-129-1-176)

Webster JR, Moenter SM, Barrell GK, Lehman MN \& Karsch FJ $1991 b$ Role of the thyroid gland in seasonal reproduction. III. Thyroidectomy blocks seasonal suppression of gonadotropin-releasing hormone secretion in sheep. Endocrinology 129 1635-1643. (doi:10.1210/endo129-3-1635)

West A, Dupre S, Yu L, Paton I, Miedzinska K, McNeilly A, Davis J, Burt D \& Loudon A 2013 Npas4 is activated by melatonin, and drives the clock gene Cry 1 in the ovine pars tuberalis. Molecular Endocrinology 27 979-989. (doi:10.1210/me.2012-1366)

Wittkowski W, Bockmann J, Kreutz MR \& Böckers TM 1999 Cell and molecular biology of the pars tuberalis of the pituitary. International Review of Cytology 185 157-194. (doi:10.1016/S00747696(08)60151-5)

Woitkewitsch A 1940 Dependence of seasonal periodicity in gonadal changes on the thyroid gland. Doklady Akademii Nauk SSSR 27 741-745.

Woodfill CJ, Wayne NL, Moenter SM \& Karsch FJ 1994 Photoperiodic synchronization of a circannual reproductive rhythm in sheep: identification of season-specific time cues. Biology of Reproduction $\mathbf{5 0}$ 965-976. (doi:10.1095/biolreprod50.4.965) 
Xu PX, Cheng J, Epstein JA \& Maas RL 1997 Mouse Eya genes are expressed during limb tendon development and encode a transcriptional activation function. PNAS 94 11974-11979. (doi:10.1073/pnas.94.22.11974)

Yasuo S \& Korf H-W 2011 The hypophysial pars tuberalis transduces photoperiodic signals via multiple pathways and messenger molecules. General and Comparative Endocrinology 172 15-22. (doi:10.1016/j.ygcen. 2010.11.006)

Yasuo S, Watanabe M, Nakao N, Takagi T, Follett BK, Ebihara S \& Yoshimura T 2005 The reciprocal switching of two thyroid hormoneactivating and -inactivating enzyme genes is involved in the photoperiodic gonadal response of Japanese quail. Endocrinology 146 2551-2554. (doi:10.1210/en.2005-0057)

Ye R, Selby CP, Ozturk N, Annayev Y \& Sancar A 2011 Biochemical analysis of the canonical model for the mammalian circadian clock. Journal of Biological Chemistry 286 25891-25902. (doi:10.1074/ jbc.M111.254680)

Yoshimura T 2013 Thyroid hormone and seasonal regulation of reproduction. Frontiers in Neuroendocrinology 34 157-166. (doi:10.1016/ j.yfrne.2013.04.002)

Yoshimura T, Yasuo S, Watanabe M, Iigo M, Yamamura T, Hirunagi K \& Ebihara S 2003 Light-induced hormone conversion of $\mathrm{T}_{4}$ to $\mathrm{T}_{3}$ regulates photoperiodic response of gonads in birds. Nature 426 178-181. (doi:10.1038/nature02117)

Zhang X, Sun H, Danila DC, Johnson SR, Zhou Y, Swearingen B \& Klibanski A 2002 Loss of expression of GADD $45 \gamma$, a growth inhibitory gene, in human pituitary adenomas: implications for tumorigenesis. Journal of Clinical Endocrinology and Metabolism 87 1262-1267. (doi:10.1210/ jcem.87.3.8315)

Received in final form 19 May 2014

Accepted 2 June 2014

Accepted Preprint published online 2 June 2014
Published by Bioscientifica Ltd 